This item was submitted to Loughborough's Research Repository by the author.

Items in Figshare are protected by copyright, with all rights reserved, unless otherwise indicated.

\title{
Retail positioning through customer satisfaction: an alternative explanation to the resource-based view
}

PLEASE CITE THE PUBLISHED VERSION

https://doi.org/10.1080/0965254x.2013.817478

\section{PUBLISHER}

(C) Taylor \& Francis

\section{VERSION}

AM (Accepted Manuscript)

\section{PUBLISHER STATEMENT}

This work is made available according to the conditions of the Creative Commons Attribution-NonCommercialNoDerivatives 4.0 International (CC BY-NC-ND 4.0) licence. Full details of this licence are available at: https://creativecommons.org/licenses/by-nc-nd/4.0/

\section{LICENCE}

CC BY-NC-ND 4.0

\section{REPOSITORY RECORD}

Siebers, Lisa Qixun, Tao Zhang, and Fei Li. 2019. "Retail Positioning Through Customer Satisfaction: An Alternative Explanation to the Resource-based View”. figshare. https://hdl.handle.net/2134/37975. 


\title{
Retail Positioning through Customer Satisfaction: An Alternative Explanation to the Resource-based View
}

\section{Dr. Lisa Qixun Siebers (Corresponding author)}

Nottingham Business School, Nottingham Trent University, Nottingham, NG1 4BU, UK.

Email: Qixun.Siebers@,ntu.ac.uk

\section{Dr. Tao Zhang}

Birmingham Business School, University of Birmingham, Birmingham, B15 2TT, UK.

Email: T.Zhang.1@bham.ac.uk

\section{Prof. Fei Li}

China Retail Research Centre, School of Economics and Management, Tsinghua University, Beijing, China, 100084.

Email: lifei@sem.tsinghua.edu.cn

\begin{abstract}
Through exploring factors influencing effective retail positioning strategies in an emerging market environment, this paper challenges the role of isolation mechanism and heterogeneous idiosyncrasy argued by the resource-based view theory. By drawing on a sample of 11,577 customers from hypermarkets, electronic appliance specialty stores and department stores in major Chinese cities, we set up ten hypotheses and confirm a nine-item model for customeroriented retail positioning (perceived price, store image, product, shopping environment, customer service, payment process, after-sales service, store policies, and shopping convenience). Our results show that different retail formats achieve success through the implementation of similar positioning strategies, in which case, it is not heterogeneity but homogeneity that contributes to retailers' success greatly at the development stage of retail expansion. Our results challenge previously proved effectiveness of inimitability to success by the resource-based view, and support homogenous idiosyncrasy of retailers in the implementation of customer-oriented positioning strategies in an emerging market.
\end{abstract}

Key words: The resource-based view, customer satisfaction, positioning strategy, anti-isolation mechanism, retailing, China

Paper type: Research paper 


\section{Introduction}

The resource-based view (RBV) argues that the competitive advantage of an organisation lies in possession of heterogeneous ownership of assets including both, tangible and intangible resources (Penrose, 1959; Wernerfelt, 1984). Scholarly work agrees that key resources of an organisation with valuable, rare, inimitable and non-substitutable nature contribute to improvement of organisational performance (Crook et al., 2008). As a result, understanding the resources of competitors determines the sustainability strength of a competitive advantage because in this way the inimitability becomes stronger. In the current paper, we identify the factors voted for by customers to inform successful retail positioning strategies and we compare these factors against the offerings of retailers. We argue that retailers transfer their retail formats into an emerging market by operating as a cohort and they further develop such formats by creating idiosyncratic offerings that become satisfactorily perceived values by customers. These perceived values form new components of customer wants and needs due to the novelty of the offerings in that market. During the transfer of new retail formats into a new market, successful retail organisations can establish effective customer-orientated positioning strategies and achieve high performance through offering homogenous values. Our arguments do not rule out inimitable nature of sustainable competitive advantage (Barney, 1986; Peteraf, 1993), however, we call for a further consideration on alternative explanations of the RBV, including an extension to the role of homogeneity as a success factor for retail businesses with various offerings in different retail formats. Our results provide new implications to further research on retail learning (Palmer, 2006), which is important for the improvement of retail experiences and utilising retail firms' resources effectively. This is particularly crucial for a retailer at the development stage of expansion in an emerging market environment with regional characteristics, such as China. 
Customer perceptions are evidenced as important components for market positioning strategies (see Stanford et al., 2012). Thus, in this paper we investigate the relationships between customer satisfaction and market positioning strategies in the retail sector in an emerging market. The reason for focusing on the retail sector is due to its power of replacing manufacturing and consequent possession of a dominant status in the world economy (see Dawson, 2007; Siebers, 2011). Further, we consider the continuous evolution of retail formats, which refer to types of retail mix used by a set of retailers (Levy \& Weitz, 2007). These are the representative retail phenomena of retail revolution in contemporary Chinese cities (see Wang, 2011). Many new formats emerged in the past two decades in China, especially supermarkets/hypermarkets have seen rapid expansion, and now they coexist with traditional retail formats such as general merchandise store, mom-and-pop stores and urban markets (Wang, 2011). Such extended diversity of retail formats provides abundant choices of for customers and creates retail format competition. The question that has been raised is: What positioning strategies shall retailers in different formats implement to sustain their competitive advantage in China as well as in other similar emerging markets?

We selected 11,577 shoppers from 11 large cities covering different geographical locations in China and collected data on factors influencing consumers' satisfaction with products and services offered by 36 large retail firms. We chose three representative retail formats hypermarkets, electronic appliance specialty stores and department stores as samples, from which customer data were collected.

Our hypotheses are mainly derived from previous scholarly work which found that a higher level of service quality leads to a higher level of customer satisfaction and positively influences 
customers' repurchase behaviours and long-term relationships with a particular retail firm (Cronin and Taylor, 1992; Zeithaml et al., 1996). We further hypothesise that the higher the levels of customer satisfaction, the higher the probability that the customers are willing to recommend the retailer to others and pay higher prices to obtain its offerings. This hypothesis illustrates a strong positive relationship between customer satisfaction on retail offerings and customer loyalty that leads to repurchase behaviours, as indicated in studies by Heskett et al. (1997) and Shoemaker and Lewis (1999).

Our results show that in China some retail offerings determine purchase choices irrespective of retail format in similarly important ways; thus, non-isolating mechanisms contribute to a similar level of retail success when the retail formats and consumption patterns are novel. This is in contrast to the RBV, highlighting that heterogeneity leads to a higher level of success. We also evidence that some key success factors are more important than others for high sales performance of a particular retail format. These factors can be used to achieve sustainability as inimitable competitive advantages, which is consistent with the RBV. Overall, we argue that retailers in different retail formats can implement homogenous positioning strategies to achieve a similar degree of success at their development stage in an emerging market; in these cases isolation and inimitability become less significant; also, retailers in the same retail format can apply various positioning strategies to differentiate themselves and achieve sustainable competitive advantages.

In the remainder of this paper we first review literature related to the RBV, positioning strategies and customer satisfaction. We then set up the hypotheses and articulate the research design and data analysis processes. After that we present the results and discuss the implications 
of these results to identify effective positioning strategies while discussing alternative explanations to the RBV in the Chinese context. Finally, we draw conclusions and shed light on future research directions.

\section{Theoretical foundations}

\subsection{The RBV and positioning strategies}

The RBV supports that competitors' inability to understand what causes the superior performance of another firm helps the one which is at the superior level to reach a sustainable competitive advantage (Lippman \& Rumelt, 1982; King, 2007). Such inter-firm causal ambiguity creates 'isolating mechanisms' (Hooley \& Greenlay, 2005: 96) that result in productivity (Grant, 1991) and thus forms barriers to the imitation of resources. In this way, firms operating with isolated competitive factors sustain their superior level. Hooley and Greenlay (2005) classify these factors into two groups: legislative restrictions, referring to property rights, and managerial practices, referring to corporate culture, managerial capabilities and information asymmetries. The RBV has been used both, academically to discuss about competitive advantage and practically to establish marketing strategies.

Strategy is defined as a central, integrated, externally oriented concept of how businesses achieve their objectives (Hambrick \& Fredrickson, 2005). A strategy articulates a certain goal and specifies how a firm aims to differentiate itself from its rivals and maintain competitive advantages (Magretta, 2002) by utilising its resources and focusing on the firm's unique position in the market place (Porter, 1996). To achieve their defined strategies, retail firms may apply various business models which change overtime according to market conditions (Sorescu et al., 2011). Theories and practice can benefit from researching on strategic positioning. We review this conceptuatlisation of positioning strategy in the context of retailing and analyse the extant 
literature of positioning strategies.

Traditionally, positioning strategies have been mainly discussed from an organisational perspective (e.g. Dibb \& Simkin, 1993; Blankson \& Kalafatis, 2004; Amonini et al., 2010). From a managerial point of view, organisations position themselves by competing and defining organisation-oriented competitive advantage through differentiation, cost leadership and focus (Porter, 1980). Firms position themselves in various ways (Amonini et al., 2010), including differentiating brand names, quality, price competitiveness, innovation and new products (Matear et al., 2004). Based on Day's (2006) service-centric firm positioning model, Amonini et al. (2010) explore competitive positioning dimensions of service firms by focusing on the utilisation of relationships, service quality, value, and brand reputation. These organisationoriented positioning strategies are largely on the basis of the management's intuition which is arguably to be insufficient because it may not be able to reflect customer values (Dibb et al., 1997). It has long been believed that positioning strategies developed from customer value standards and perceptions channel resources function more effectively and meet customer expectations better (Zeithaml, 1988). Therefore, setting up effective positioning strategies by involving customer perceptions minimises the gaps between customer expectations and offerings of firms (Ries \& Trout, 1986).

Literature on scale development underscores the appropriateness of speaking directly to customers, as argued by Sweeney et al. (2000) and Izquierdo et al. (2005). These arguments are supported by the RBV theory in which a competitive positioning strategy expects a clear view of customer requirements (see Hooley \& Greenley, 2005; Dibb \& Simkin, 1993; Hooley \& Saunders 1993; Bhat \& Reddy, 1998). Indeed, some studies on firm positioning have emphasised 
the importance of customers (e.g. Treacy \& Wiersema, 1994; Durvasula et al., 1999; Crawford \& Mathews, 2001; Ander \& Stern, 2004). However, the foregoing has mainly focused on four elements that have an effect on customer satisfaction: perceived price, products, customer service and shopping environment. The analysis of these four factors is far less sufficient to achieve a high level of satisfaction of customers who have become increasingly more demanding and complex (Blankson \& Kalafatis, 2004), particularly in an emerging market (see Uncles, 2010; Siebers, 2012). Little research has been conducted addressing the positioning strategies of retailers in general and retailers in China in particular considering their behaviours and characteristics (Kåre \& Kjell, 2010). To fill this gap one of the goals of our paper is to develop customer-oriented retail positioning strategies by analysing chosen retailers' key success factors in satisfying customers.

Ries and Trout (1986) state that positioning of retail firms often refers to the way products and services are perceived by customers and therefore a successful positioning strategy is only able to be obtained from a customer perspective, as concurred by Blankson and Kalafatis (2004). Based on this approach, several authors have suggested competitive retail positioning models involving different dimensions, e.g. the three-dimension model: operational excellence, product leadership and customer intimacy (Treacy \& Wiersema, 1994); the five-dimension model: price, products, access, experience and services (Crawford \& Mathews, 2001); or variety of products, low prices, fashion, convenience and efficiency (Ander \& Stern, 2004); and the six-dimension model: price, technical quality, service, innovation, customization, and uniqueness (Hooley et al., 2004). These authors suggest that in order to be successful, retail companies only need to be outstanding in one of these aspects and at average or pass levels in the remaining aspects. Other authors imply that retailers may compete by offering more than one competitive positioning 
element (Matear et al., 2004; Kalafatis et al., 2000).

Despite of the increasing number of similar competitive positioning elements offered by firms over a certain period of time, the RBV emphasises that firm heterogeneity is significant to achieve competitive advantages because of the barriers to imitation (Rumelt, 1991). Mauri and Michaels (1998) argue that the RBV neglects the potential, that dominance of industry effects over time may show similarities in response to an industry environment and the imitation of successful strategies. Based on this conflicting theoretical guidance, the authors conducted an empirical study and found that the predominance of firm effects is significant but not on core strategies including technology and marketing. Furthermore, industry effects are more important for forming these core strategies. Their findings call for more attention for the predominance of market structure, in which convergent patterns of competition may become common industry characteristics over time, because firms are able to reduce competitive gaps by imitating successful firms' valuable resources. According to these arguments, attention on strategic choices needs to be given to the market structure and market conditions. As such, the emerging markets provide a unique opportunity to advance our understanding on the RBV and analyse the appropriateness of homogeneity and heterogeneity, not only at a later stage of market expansion when similar marketing strategies may be seen, but even at the development stage of market expansion when firms face dynamically changing new market conditions.

\subsection{Changes of retail structure and consumer values in the Chinese context}

According to Schmitz (2009), perceived acquisition value of shopping at a retail format plays an important role in customers' preferences for retail formats. In recent years, new retail formats have been the emergence in the urban retail landscape in China (Wang, 2011), impacted by the burgeoning consumerism, new consumption patterns and consumer revolution (Hanser, 2005). 
Various definitions of 'retail format' are in relation to retail institutions (Brown, 1987), retail strategy mixes (Berman \& Evans, 2001) or offering, know-how, retail technology, and retail culture (Goldman, 2001). Au-Yeung's (2003: 136) interpretation 'that retail format refers to physical elements and appearance of a retail outlet that is visible to consumers, including merchandise assortment, store atmosphere, services inside the store, physical location and price', has been used by Wang (2011) to analyse the retail revolution in urban China. The present paper also adopts this definition in order to understand what factors have impacts on customer satisfaction of different retail formats in China and which strategic positioning choices retailers shall make for their offerings to Chinese consumers.

In the Chinese retail market a convergence towards international norms is evident from the aspects of retail structure and consumer demand. Western retail formats, infrastructure and management practices have been transferred into the Chinese market (Uncles 2010) and new retail strategies have been formed (Dawson, 2004; Siebers \& Kamoche, 2012). In grocery retailing, supermarkets and hypermarkets have seen the fastest growth compared to any other format, with value growth rates at 29 percent and 17 percent respectively from 2003-2008 (Euromonitor, 2009). Beyond the grocery sector, electronic appliance specialty stores expanded the most with a value growth rate of 21 percent during the same period. These dynamic changes in consumption patterns require an up-to-date understanding of customer values and satisfaction in China.

\subsection{Hypotheses}

When assessing customer satisfaction, the literature in marketing mainly focuses on customer feedback from price, service quality, store image, product, shopping environment and shopping convenience (see Table 1 for literature summary). We now discuss these factors in turn and in the 
context of China (as appropriate).

Price is the most commonly used indicator of customer involvement (Rothschild, 1979). In reality, consumers do not always know or remember the actual price of products but they do normally encode prices in ways that are meaningful to them such as a number or "expensive" or "cheap" (Dicken \& Sawyer, 1985). In addition, the concept of perceived price has been introduced by taking into account not only the monetary price but also time, efforts, search costs and psychic costs involved in the purchase process (Grewal et al., 2011; Becker, 1965; Zeithaml, 1988). In the European market price is the most important reason for customers to shop in discount stores, e.g. in Germany (see Schmitz, 2009); however, in the US market, price is not ranked in the top five attractive attributes for supercentre and grocery store shoppers (see Carpenter and Moore, 2006). In recent research on China's retail sector, Chang and Luan (2010) found that consumers in Beijing are more concerned with a retailer's reputation and services than with the price in hypermarkets. This implies a new trend of consumer shopping behaviour in large Chinese cities. In order to understand the role of price in influencing customer satisfaction in various retail formats across large Chinese cities, we propose:

H1: Lower price is positively related to customer satisfaction in large Chinese cities regardless of retail format and geographical location of the city.

Store image such as store layout, architecture, symbols, colors and sales personnel draw attention of shoppers and determine the success of retail stores (Martineau, 1958). Grewal et al. (2003) propose that shoppers' evaluations of the store atmosphere affect their perceptions of value and further their store patronage intentions. Further, the retail store atmosphere has a positive influence on consumers' patronage intentions (Van Kehove \& Desumaux, 1997), creating customer intimacy (Treacy \& Wiersema, 1994), and nice feeling and reputation 
(Thompson \& Chen, 1998). Overall, a superior store image over that of competitors creates a reason for customers to shop at a particular retail store (Auken \& Lonial, 1991) and becomes a part of retail offerings (Hoffman \& Turley, 2002). Store atmosphere has been considered as the most important factor by customers of hypermarkets in Beijing, with regards to store image dimensions (see Chang and Luan, 2010). We propose that:

H2: Store image is positively related to customer satisfaction in large Chinese cities regardless of retail format and geographical location of the city.

Product is a controllable factor that influences consumers' patronage decisions. Having desirable products priced at a desirable level is fundamental to any retail strategy (Grewal et al., 2003). Varieties, fashion (Ander \& Stern, 2004), innovation and uniqueness (Hooley et al., 2004) all increase consumers' patronage and purchase decisions. Consequently, product leadership is a significant factor for retail success (Treacy \& Wiersema, 1994; Crawford \& Mathews, 2001). There has been less explicit exploration and discussion about the increasing power of retailers on influences over consumer choices for products (Dawson, 2013). It is important to explore further how such choices provided by retailers have impacts on customer satisfaction. Thus we propose:

H3: roduct is positively related to customer satisfaction in large Chinese cities regardless of retail formats and geographical location of the city.

Shopping environment has become a tool for market differentiation (Levy \& Weitz, 1995). Physical surroundings of a store, such as music, lighting, layout, directional signage and human elements, influence customer shopping behaviours (Baker \& Cameron, 1996; Lam, 2001). store layout (e.g. the ease of locating desired merchandise and the ease of moving around in the store) has significant effects on customer satisfaction (Titus \& Everett, 1995). Moreover, the shopping environment has impacts on various stages of shoppers' cognitive process, including attention, 
perception, categorization and information processing (Lam, 2001). Research suggests that perceived waiting times vary with the valence of music and the external appearance of the store (Hui et al., 1997; Ward et al., 1992). Providing a store environment with engagement and fun will improve customers' evaluation of shopping experience (Puccinelli et al., 2009). Thus we propose:

H4: Shopping environment is positively related to customer satisfaction in large Chinese cities regardless of retail formats and geographical location of the city.

Service quality normally refers to in-store experiences, such as interactions with employees, merchandise, quality, and availability of merchandise. These are important factors that influence retail customer satisfaction (Dabholkar et al., 1996). In the Chinese context, the word for service is fuwu (see Wang, 2011), which is derived from the Communist slogan 'serve the people' (wei renmin fuwu), and this concept has been developed into the virtue of selflessness related to social harmony and national progress. This concept is refining the meaning of service and has an impact on China's currently consumer-drive economy. Wang et al. (2004) identified the role of the four dimensions of customer value (functional, social, emotional and customer-perceived sacrifice), which all have a significant effect on customer satisfaction. The authors further argue that Chinese consumers are becoming more mature, preferring functional value rather than the other three kinds of value when making behavioral decisions. These findings suggest that firms can create competitive advantage by continuously improving customer relationship management. Both, the Chinese market and Chinese consumers are constantly changing; however, research on the relationship between customer service and Chinese customer satisfaction remains under developed. We therefore hypothesise the following:

H5: Customer service is positively related to customer satisfaction in large Chinese cities regardless of retail formats and geographical location of the city. 
Researchers found that after-sales services and store policies (e.g. the ease with which stores refund or exchange merchandise) are important to customers' perception and evaluation of retail stores (Dabholkar, Thorpe \& Rentz, 1996; Mazursby \& Jacoby, 1985; Oliver, 1981). We therefore propose:

H6: Payment process is positively related to customer satisfaction in large Chinese cities regardless of retail formats and geographical location of the city.

H7: After-sales service is positively related to customer satisfaction in large Chinese cities regardless of retail formats and geographical location of the city.

H8: Store policies are positively related to customer satisfaction in large Chinese cities regardless of retail formats and geographical location of the city.

Shopping convenience such as access (Crawford \& Mathews, 2001) or efficiency of customer efforts (Ander \& Stern, 2004) also has a big impact on customers' evaluation of retail stores. Based on the review and discussions of literature, we further propose:

H9: Store facilities are positively related to customer satisfaction in large Chinese cities regardless of retail formats.

H10: Purchase convenience is positively related to customer satisfaction in large Chinese cities regardless of retail formats.

Table 1 summarises the main elements and factors found in the literature that analyse customer satisfaction in a retailing setting.

\section{'Insert Table 1 here'}

In the following sections we will investigate how these factors influence customer satisfaction of Chinese shoppers and how these factors are considered in the effective positioning strategies by retailers in the chosen three retail formats: hypermarkets, electronic appliance speciality stores and department stores. In this way, we suggest customer-oriented positioning 
strategies to respond to dynamic customer demands. We then discuss how retailers implement these strategies, utilising their resources, to achieve competitive advantage in relation to the RBV. In order to ensure the validity and reliability of factors addressed in our hypotheses and ensure that these factors are suitable to reflect satisfaction of Chinese consumers, we conducted a pilot study to test the factors to be adopted in our base model.

\section{Research design and methodology}

\subsection{The pilot study and the model}

In the beginning we conducted a pilot study to confirm the factors influencing customer satisfaction in China and to finalise our theoretical model. For this purpose we applied the lens of consumers approach (Johnson \& Gustafsson, 2000) to allow our selected consumers to inform us about the factors influencing their satisfaction.

For fully understanding customer motivations and expectations in a particular market indepth market research and focus group discussions are required (Dibb et al., 1997; Blankson \& Kalfatis, 2004). Thus, we set up six focus groups, two groups for each retail format, and allocated one group leader with eight to ten members who had sufficient shopping experience in the given retail format in each focus group. The groups discussed about their experiences before purchase, during purchase, and after purchase from these three different retail formats. Then we obtain data from 306 sample customers to refine our measurement set up in our hypotheses: 106 of hypermarkets, 100 of electrical appliance speciality stores and 100 of department stores. We conducted random telephone interviews with customers of hypermarkets and electrical appliance speciality stores; and we conducted face-to-face interviews with those of department stores, to minimize coverage errors (Lohr, 2008) and non-response error (Groves et al., 2004). We applied 
exploratory factor analysis to analyse the data and the results show that the ten items identified in our hypotheses influence the satisfaction of 62 customers of hypermarkets $(58 \%), 61$ customers of electrical appliance speciality stores $(61 \%)$ and 55 customers of department stores (55\%). To justify the reliability of the data, we used exploratory factor analysis (EFA) and obtained the ten factors that influence customer satisfaction set up in our hypotheses. We refined the measurements by considering the size of the factor loadings through reducing the factors with lower loadings, until they became ideal. Finally, we obtained 34 items in total to reflect these ten factors (the detail is presented in Table 4) to design the questionnaire. Moreover, we defined four indicators (overall satisfactory, satisfactory as expected, comparably satisfactory and ideally satisfactory) to assess customer satisfaction; and also three indicators (purchase again, recommendations to other customers, purchase again at increased prices) to assess customer loyalty resulted from customer satisfaction (customer loyalty is not the main focus of this current paper). Our drafted model is shown in Figure 1. 


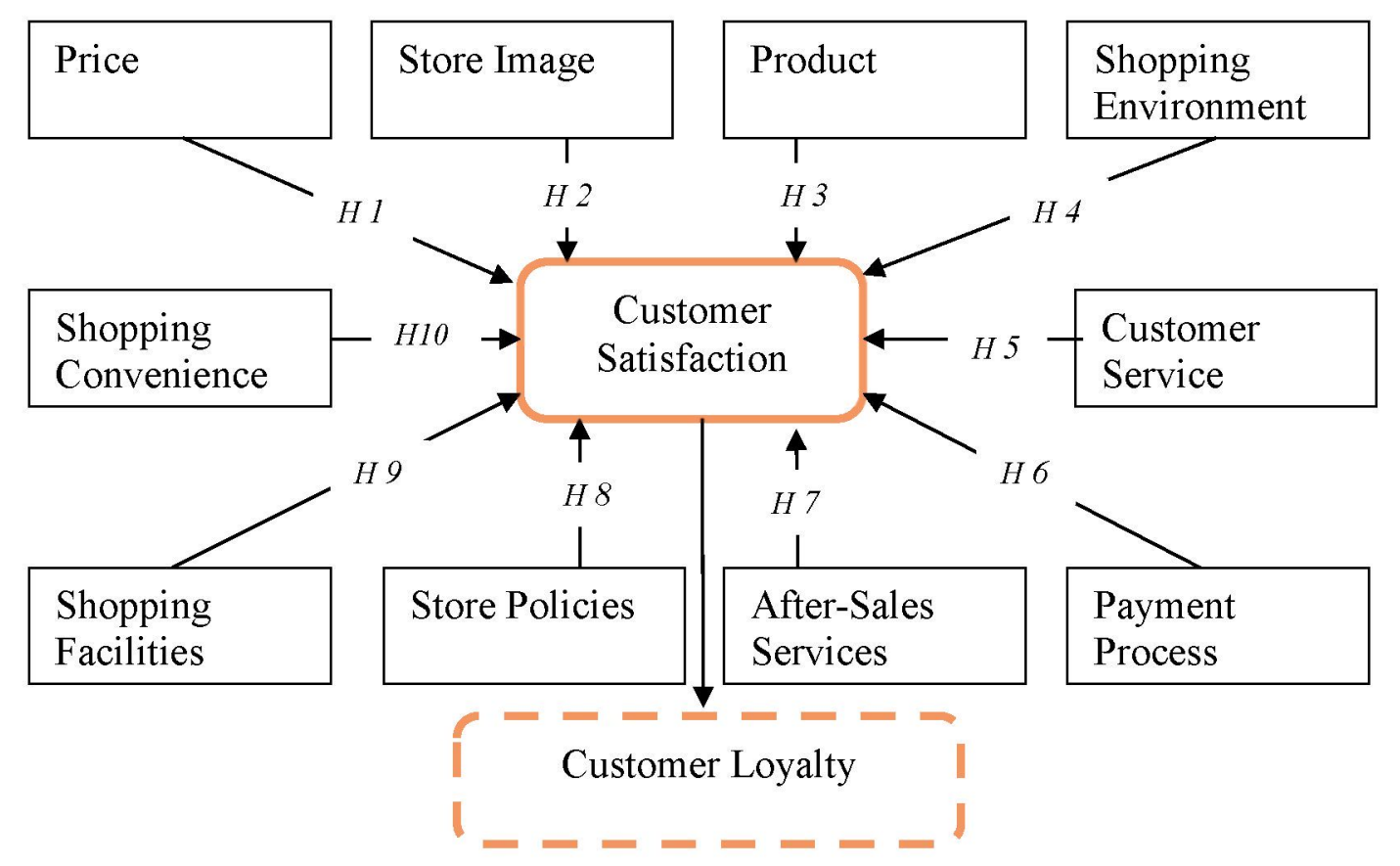

Figure 1 Retail customer satisfaction measurement model

\subsection{Retailer and location selection}

In order to identify the appropriate retail formats and retailers for the investigation we used a multi-step strategy.

Firstly, we used certainty probability to select retail formats: we choose the most representative retail formats in China, including the most popular format that foreign retailers transferred into China, hypermarket (Goldman, 2001) and established retail formats electrical appliance specialist stores and department stores (Wang, 2003). Both hypermarkets and electronic appliance speciality stores are one of retail formats showing the fastest growth trend between 2003 and 2008 as mentioned earlier (see Euromonitor 2009). According to the Classification of Retail Format in China (Beijing.gov, 2006), a hypermarket refers as a one-stopshopping retail store over $6,000 \mathrm{~m} 2$, with comprehensive merchandise, and hypermarket was introduced into China in the mid-1990s; an electrical appliance specialty store refers to a shop that mainly specialises in home appliance; and a department store refers to a building open to the public which offers a wide range of consumer goods and implements standard management 
systems, selling products in different regions and aiming to respond to customers demand for variety and stylish products, and department stores first appeared in China in the early $20^{\text {th }}$ century.

Secondly, we selected the top 36 retailers $(n=36)$ by sales according to the list of top 100 retail chain enterprises by China Chain Store Almanac (2005). These retailers include top 20 hypermarkets, top six electrical appliance speciality stores and top ten department stores.

Thirdly, in order to identify successful retailers in each format, we searched for retailers which have three criteria (customer satisfaction, customer loyalty and store image) higher than the average level within the same retail format respectively. These have been used frequently for identifying successful retail firms (see Souitaris \& Balabanis, 2007; Babakus et al., 2004; Bloemer et al., 1998). We found 15 retailers that fulfilled the above requirements and can therefore be labeled "successful", including eight hypermarkets (Darunfa, Wal-Mart, JUSCO, Auchans, Hymall, Metro, Carrefour, Ito-Yokado), three electrical appliance specialty stores (Sanlian, Wuxing and Guomei) and four department stores (Beijing Cuiwei Mansion, Beijing Saite, Beijing Wang Fujing and Shanghai Nol. Ba Baiban). We define the rest 21 retailers as "towards-successful" retailers, including 12 hypermarkets (Shenzhen Baijia, Beijing Hualian, Shanghai Gongnongshang, Lotus, Suguo, Beijing Wumei, Haoyouduo, Makro, Xinyijia, Huarunwanjia, Shanghai Hualian, Shangahai Lianhua); three electrical appliance speciality stores (Suning, Dazhong, Yongle); and six department stores (Beijing Baisheng, Shanghai Pacific Department Store Xujiahui Branch, Yansha Friendship Shopping Mall, Shanghai East Mansion, Shanghai New World, Shanghai No.1 Department Store)

In order to identify locations, firstly, we applied certainty probability (Groves et al., 2004) to 
ensure the overall coverage of the geographical domains of China: North, East, South Middle and West China. The certainty probability sampling process helps to reduce coverage error (Groves et al., 2004). Secondly, we use disproportionate stratification (Groves et al., 2004) to gain precision for an overall estimator of selection by population with size based on the 2010 China census data. We select: Shanghai (the largest city, East China), Beijing (the second largest city, North China), Tianjin (the fourth largest city, North China), Guangzhou (the fifth largest city, South China), Wuhan (the sixth largest city, Middle China); Chongqing (the seventh largest

city, Southwest China), Nanjing (the ninth largest city, East China);Chengdu (the $11^{\text {th }}$ largest city, Southwest China); Jinan (the $13^{\text {th }}$ largest city, North China), Qingdao (19 ${ }^{\text {th }}$ largest city, North China), and Shenzhen (special economic zone, South China). These cities have population size between one and eleven million. Third, these cities have higher economic development level compared to their neighboring cities, and are the major locations where foreign retailers expand aggressively by transferring the modern retail formats (Siebers, 2011).

\subsection{Sampling and data collection}

In order to ensure that the selected consumers are representative, the distribution of the samples considers the number of stores owned by each firm in each city. We applied a two-step mixed data collection method. Firstly we applied random telephone interviewing with customers of hypermarkets and electrical appliance speciality stores in order to be cost efficient and gain better coverage of population (Fowler, 2009). We used probability sampling in form of random digital dialling (RDD) to reduce bias and we used a computer-assisted telephone interviewing (CATI) system to assist the conduction of telephone interviews with customers of the hypermarkets and electrical appliance speciality stores. CATI provides a structured system of data collection by telephone which expedites the collection and assists the interviewer to educate 
the respondents on provision of timely and accurate data. Secondly we applied non-probability sampling and conducted face-to-face interviews with customers of department stores to ensure data quality (Fowler, 2009). When selecting face-to-face interviewees, we used a qualified convenience sample and different-aged consumers, as suggested by Walsh et al. (2010). These customers were shopping at the chosen department stores; therefore the creation of the customer sample list and the process of sampling occur simultaneously (Fowler, 2009). The mixed modes of data collection allowed us to minimize coverage errors (Lohr, 2008) and non-response error (Groves et al., 2004).

\subsection{Sample characteristics}

To assess the reliability and validity of the measurement scale, our sample frame is defined as consisting of people in accordance with three conditions: (1) older than 18 years of age; (2) neither the respondent or the family of him/her is engaged in the retail, marketing or advertising work; (3) have not been involved in any retail-related market research within the past six months. The proportion of men and women in our samples was $49 \%$ and $51 \%$ respectively, which is generally consistent with previous consumer research data of the proportion between male and female with minimum gender bias. For example, Arnett et al. (2010) draw a sample with male $44 \%$ and female $56 \%$ to investigate retail-manufacturer brand alliances. In our sample, more than $40 \%$ of respondents are between 18 and 29 years old and more than $50 \%$ have a diploma or above degree. Appendix 1 provides a description of the sample characteristics.

We draw the number of between 250 and 500 sample customers from each hypermarket, electrical appliance speciality stores and department store. The final distribution of respondents among the three retail formats is: $n=5,019$ for hypermarkets, $n=1,514$ for electrical appliance speciality stores and $n=5,044$ for department stores. Thus, a total of samples of 11,577 have been 
drawn. After eliminating the odd samples, 9,283 effective samples have been obtained, representing approximately an $80 \%$ of response rate $(n=11,577)$. Therefore, the final sample size is $n=9,283$. We conducted these investigations in the year of 2007 .

Our questionnaires have been designed to cover all ten items which have been sub-divided into a total of 34 sub-items, plus two questions related to the degree of customer satisfaction and customer loyalty, making up 41 sub-items in total. In the questionnaires, we use a ten-item scale to assess each entry, score 1 being the lowest and score 10 being the highest, which has been recommended by Ryan et al. (1995) as a suitable measurement scale for assessing customer satisfaction.

\subsection{Measures}

We studied the ten factors in our theoretical model. For testing the reliability of our real world data we used Cronbach's alpha (Cronbach's $\alpha$ ), which is a coefficient of internal consistency, normally used as an estimate of the reliability of a sample of examinees (Nunnally, 1978). The factor "price" comprises three attributes (reasonable price, competitive price and attractive promotion) and has a Cronbach's $\alpha$ of .83 for hypermarkets, .82 for electronic appliance speciality stores and .86 for department stores. The factor "store image" comprises four attributes (famousness, store reputation, trust and social responsibility) and has a Cronbach's $\alpha$ of .84 for hypermarkets, .85 for electronic appliance speciality stores and .86 for department stores. The factor "product" comprises three attributes (top of the range, easy to be found, neat display) and has a Cronbach's $\alpha$ of .84 for hypermarkets, .83 for electronic appliance speciality stores and .86 for department stores. The factor "shopping environment" comprises four attributes (spaciousness, cleanness, atmosphere and layout) and has a Cronbach's $\alpha$ of .86 for hypermarkets, .86 for electronic appliance speciality stores and .87 for department stores. The 
factor "customer service" comprises six attributes (willingness to help, ability to help, appearance and behaviour, attitude, reliability and prompt help) and has a Cronbach's $\alpha$ of .93 for hypermarkets, .93 for electronic appliance speciality stores and .91 for department stores. The factor "payment process" comprises three attributes (checkout accuracy, payment methods and checkout speed) and has a Cronbach's $\alpha$ of .77 for hypermarkets, .77 for electronic appliance speciality stores and .78 for department stores. The factor "after-sales service" comprises two attributes (prompt delivery and assembling and prompt repair) and has a Cronbach's $\alpha$ of .80 for hypermarkets, .75 for electronic appliance speciality stores and .78 for department stores. The factor "store policies" has a single attribute (refund policies) and has a Cronbach's $\alpha$ of .80 for department stores only. This is because of the special characteristics of Chinese department stores and will be explained further in the results and discussion section. The factor "store facilities" comprises three attributes (trolleys and baskets, washrooms and rest facilities) and has a Cronbach's $a$ of .71 for hypermarkets, .70 for electronic appliance speciality stores and .80 for department stores. The factor "shopping convenience" comprises four attributes (opening hours, convenient location, easy parking and easy storage of personnel belongings) and has a Cronbach's $\alpha$ of .71 for hypermarkets, .71 for electronic appliance speciality stores and .75 for department stores. These results of Cronbach's $\alpha$ indicate that the internal consistency of the scale items is acceptable, because when $0.7 \leq \alpha$, the internal consistency has been proved being acceptable suggested by Nunnally (1978). The mean values of the marketing mix variables, customer satisfaction and loyalty for the three retail formats are in Table 2.

(Insert Table 2 here)

\subsection{Data analysis}

Partial least square (PLS) regression has been used to analyse our large data set, allowing construct variables and observed variables to have abnormal distribution. Using the PLS method 
allows reflective indicators to show a function of their associated latent variables (Moorman et al., 1993). It has been identified as an appropriate method for research on customer satisfaction with predictive purpose by Fornell \& Larcker (1981).

We use the following formula for our data analysis: $n$ : sample size; $m$ : number of construct variables; $Z_{1}, Z_{2}, \ldots Z_{\mathrm{m}}$ : each construct variables; each construct variable $Z_{k}$ has the number of observed variables $\mathrm{P}_{\mathrm{k}}$ : $\mathrm{X}_{\mathrm{k} 1}, \mathrm{X}_{\mathrm{k} 2}, \ldots, \mathrm{X}_{\mathrm{kpk}}, \mathrm{P}_{\mathrm{k}}$, which form a matrix of $n \times \mathrm{P}_{\mathrm{k}}$; the vector was formed by the regression coefficient from the observed variables matrix $X_{k}$ to construct variables matrix $Z_{\mathrm{k}}$ is $w_{k}$, therefore, $Z_{\mathrm{k}}=\mathrm{X}_{\mathrm{kwk}}$.

Adopting the calculation methods of Lohmoller (1989), we take three steps to analyse the data: (1) Data processing: we standardised the observed variables and the data after standardisation kept as matrix $\mathrm{X}_{1}, \mathrm{X}_{2}, \ldots \mathrm{X}_{\mathrm{m}}$; and we finalise the original regression coefficient vector $w_{k}{ }^{(0)}, k=1,2, \ldots, \mathrm{m}$. (2) We process recurrent iteration, until the regression coefficient matrix converges ( $s$ times). Therefore, we have:

a) $\mathrm{Z}_{\mathrm{k}}^{(\mathrm{s})}=\mathrm{f}_{\mathrm{k}} \mathrm{X}_{\mathrm{k}} \mathrm{w}_{\mathrm{k}}^{(\mathrm{s})}, \quad 1 \leq \mathrm{k} \leq \mathrm{m}$;

b) $\tilde{\mathrm{Z}}_{\mathrm{k}}^{(\mathrm{s})}=\sum_{\mathrm{i}=1}^{\mathrm{k}} \mathrm{c}_{\mathrm{ki}} \mathrm{Z}_{\mathrm{i}}^{(\mathrm{s})}, 1 \leq \mathrm{k} \leq \mathrm{m}$;

$\mathrm{c}_{k i}=\left\{\begin{array}{l}0, \text { there is a path retlationship between } \mathrm{Z}_{\mathrm{k}} \text { and } \mathrm{Z}_{\mathrm{i}} \\ 1 \text {, there is a path retlationship between } \mathrm{Z}_{\mathrm{k}} \text { and } \mathrm{Z}_{\mathrm{i}} \text {, and } \mathrm{r}\left(\mathrm{Z}_{\mathrm{k}}^{(\mathrm{s})}, \mathrm{Z}_{\mathrm{i}}^{(\mathrm{s})}\right)>0 \\ -1 \text {, there is a path relationship between } \mathrm{Z}_{\mathrm{k}} \text { and } \mathrm{Z}_{\mathrm{i}} \text {, and } \mathrm{r}\left(\mathrm{Z}_{\mathrm{k}}^{(\mathrm{s})}, \mathrm{Z}_{\mathrm{i}}^{(\mathrm{s})}\right)<0\end{array}\right.$

c) $\quad \mathrm{w}_{\mathrm{k}}^{(\mathrm{s}+1)}=\frac{1}{\mathrm{Z}_{\mathrm{k}}^{(\mathrm{s}) \prime} \mathrm{Z}_{\mathrm{k}}^{(\mathrm{s})}} \mathrm{X}_{\mathrm{k}}^{\prime} \mathrm{Z}_{\mathrm{k}}^{(\mathrm{s})}, \quad 1 \leq \mathrm{k} \leq \mathrm{m}$.

$\tilde{f}_{k}$ is a standard factor, that is to standardize the value of $\mathrm{X}_{\mathrm{k}} \mathrm{W}_{\mathrm{k}}^{(\mathrm{s})} \cdot \mathrm{c}_{\mathrm{ki}}$ is the weight coefficient of construct variables. Formula c) is the unitary regression coefficient for the new regression 
coefficient vector $\mathrm{w}_{\mathrm{k}}^{(\mathrm{s}+1)}$, derived from the previous iteration between construct variables $\mathrm{Z}_{\mathrm{k}}^{(\mathrm{s})}$ and each observed variables among $\mathrm{X}_{\mathrm{k}}^{\prime}$ factors. We define the convergence conditions of the regression coefficient matrix as $\left|\mathrm{w}^{(\mathrm{s})}-\mathrm{w}^{(\mathrm{s}+1)}\right|<10^{-5}$ or $\left|\left(\mathrm{w}^{(\mathrm{s})}-\mathrm{w}^{(\mathrm{s}+1)}\right) / \mathrm{w}^{(\mathrm{s})}\right|<10^{-5}$.

Through the value of $w_{k}$ we calculated the weight of construct variable $Z_{\mathrm{k}}$ and then obtained the relationships of the latent variables. These are presented in Table 4.

\section{Results}

We applied verification of scale analysis to test the ten refined items and ensured that they have good reliability to examine the determinants of the degree of customer satisfaction. Adopting the structural equation modelling method (Jöreskog \& Sörbom, 1993), we tested the ten-item model for the three retail formats respectively, and examine the construct reliability by confirmatory factor analysis (CFA) as suggested by Blankson and Kalafatis (2004). The overall model's chisquared, the CFA criteria, the Cronbach's $\alpha$, item-total correlation and the item regression loadings have been used to assess the model fit. The results of the verification of the scale analyses are shown in Table 3. According to Table 3, all the construct values for the three retail formats are within the recommended criteria: the root mean square error of approximation, RMSEA $<.06$, which meets the more recently cut-off value suggested by Hu and Bentler (1999); the goodness-of-fit index (GFI) values and the adjusted goodness-of-fit index (AGFI) values are controversial because it has upwards and downwards bias depending on the sample size (Hopper et al., 2008) and previous studies accept a up to .95 GFI value (Miles \& Shevlin, 1998). In general, an AGFI value at about 90 is accepted (Hooper et al., 2008); standardised root mean square residual (SRMR) is valid at less than .05 (Byrne, 1998); the comparative fit index (CFI) is least effected by sample size (Fan et al., 1999) and a value greater than 90 is acceptable to ensure specified models (Hu \& Bentler, 1999; Stanford et al., 2012); the non-normed fit index 
(NNFI) is above .90, which meets the cut-off criteria suggested by Hooper et al., (2008). Therefore, the ten-item version model is fundamentally appropriate.

(Insert Table 3 here)

We present two groups of results from our data analysis. The first group focuses on various benefits in the proposed retail customer satisfaction measurement model. Through the PLS calculation (Fornell \& Larcker, 1981), the results show that the ten construct variables have different degrees of influence on customer satisfaction when compared to perceived benefits by customers; and these differences are not completely related to various retail formats. Customers do however, to some extent, expect different retail offerings from different retail formats, which are shown in Table 4.

\section{(Insert Table 4 here)}

According to Table 4, the five most influential items/retail offerings that satisfy Chinese customers of the hypermarkets are: price, store image, products, shopping environment, and customer services $(p<0.001)$. For electrical appliance speciality stores these are: store image, price, customer services, products, and shopping environment $(p<0.001)$. For department stores these are: store policies, store image, after-sales service, price, and customer service $(p<0.001)$. Moreover, the significance of store facilities and shopping convenience is rejected by both hypermarkets and electronic appliance speciality stores; and the significance of store facilities is also rejected by department stores. These results imply that any further improvement on these items may not increase the level of customer satisfaction toward the relevant retail format.

It is notable that the level of importance among the customer expected benefits/retail offerings share a similar trend. Figure 2 compares the different impacts each item has on customer satisfaction of three retail formats. According to Figure 2, store policies, after-sales 
services and store image are particular concerns for customers of department stores. Further improvement on store image provides more benefits to customers of electronic appliance speciality stores and department stores than those of hypermarkets. Price is more influential for customer satisfaction in hypermarkets, and further improvement on shopping convenience provides more benefits for department store shoppers.

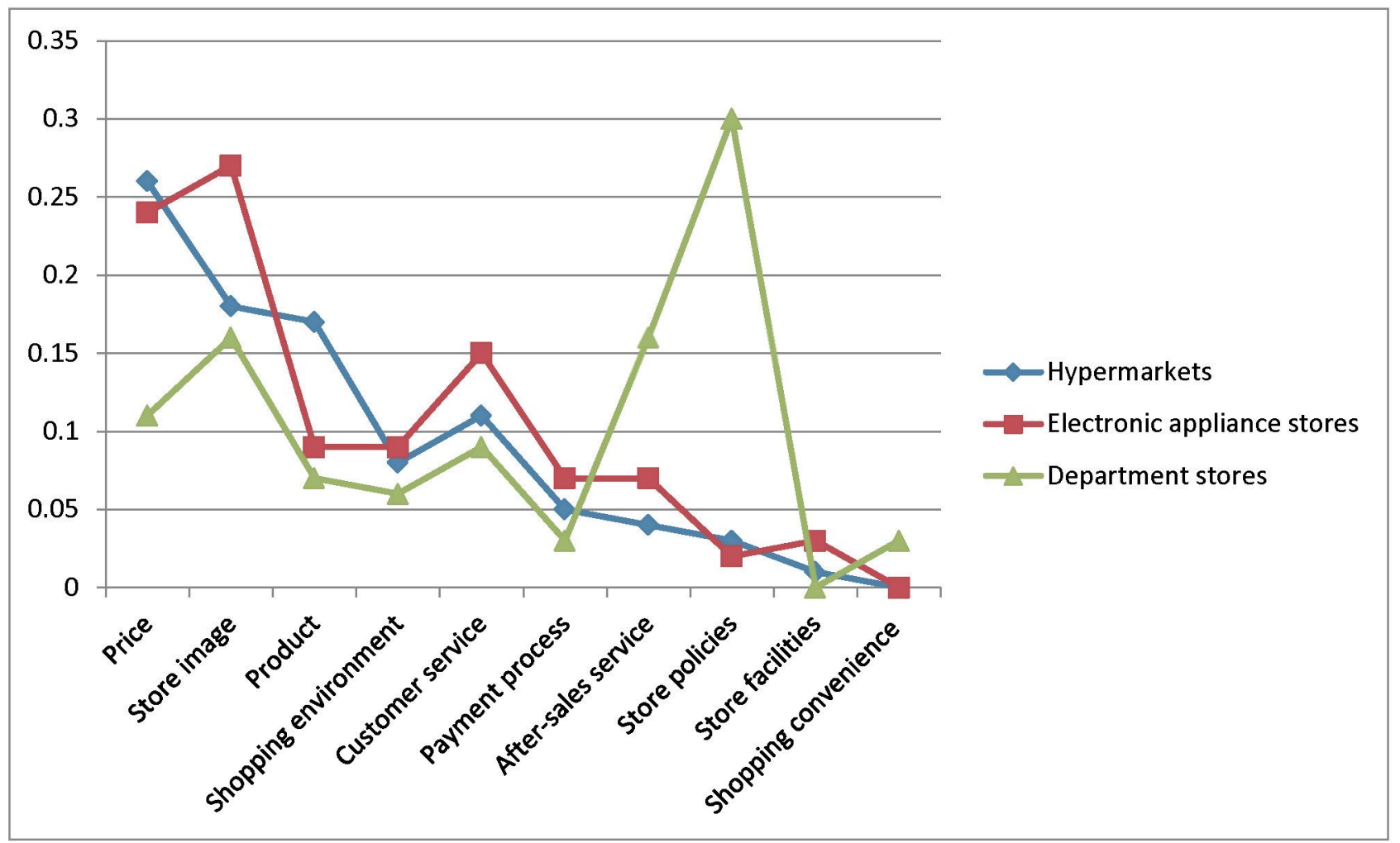

Figure 2 Comparison of effects of retail offerings on customer satisfaction

The second group of the results present the retail offerings from "successful" and "towardssuccessful" retailers of three formats, shown in Table 5.

(Insert Table 5 here)

We present three parts of results according to Table 5. The first part is on hypermarkets: (1) among eight "successful" hypermarkets, six of them provided one distinctive benefit to satisfy their consumers, as their primary positioning item which include price, service, shopping 
environment and product; five out of these six hypermarkets had a secondary positioning item; two have neither a clear primary positioning item nor a secondary positioning item; (2) for "towards-successful" hypermarkets, most of the scores for non-positioning items are higher than those of the average industrial level; (3) none of the 12 "towards-successful" hypermarkets have any clear positioning item.

The second part of the results is on electronic appliance speciality stores: (1) two out of three "successful" electrical appliance speciality stores have both primary and secondary positioning items; one has neither (this may be because the retailer only developed its businesses in Shandong province, without any strong competitors, therefore achieved high customer satisfaction); (2) the scores for non-positioning items are all higher than those of the average industrial level; (3) the positioning items of "successful" stores focus on two factors: price and service; (4) three "towards-successful" appliance speciality stores do not have any clear positioning item The results imply that having a positioning item is not the only key success factor for both hypermarkets and electronic appliance speciality stores.

The third part of our results is on department stores: (1) three out of four "successful" department stores have both primary and secondary positioning items; one has neither; (2) the scores for non-positioning items of "successful" department stores are all higher than those of the average industrial level; (3) the primary positioning items of "successful" department stores focus on service, shopping environment, store policies and price; (4) two out of six "towardssuccessful" department stores have positioning items to satisfy their consumers; the other four department stores do not show any clear positioning items that are more competitive than those of their rivals; (5) most of the scores for non-positioning items of the six "towards-successful" 
department stores were at the same as or lower than those of the average industrial level. Department stores show a mixed results on particular benefits offered to their customers. This is likely related to the fact that department store has been a traditional retail format in China even with updated offerings. They are popular by any means despite of customer expectations on improved store polices, after-sales services and shopping convenience.

\section{Discussion and implications}

\subsection{Retail formats, positioning strategies and competitive advantage}

Our results offer three main contributions to knowledge considering various retail formats. First, we used a drafted ten-item model to test strategic positioning items of different retail formats assessed from a customer perspective. Among the ten items we tested, we confirmed that Chinese customers from all the three retail formats consider eight items as satisfactory criteria: price, store image, product, shopping environment, customer service, payment process, aftersales service, and store policies. Any retailer that provides such benefits has potential to sustain their competitive advantages, irrespective of its retail format. Moreover, the significance of store facilities is rejected by all three retail formats, and shopping convenience is rejected by both hypermarkets and electronic appliance speciality store. These results imply that any further improvement on store facilities may not influence the extent of customer satisfaction; and this is the same case for shopping convenience of hypermarket and electronic appliance speciality stores. Thus, our confirmed new model comprises nine items that influence retail customer satisfaction in the context of China, showing in Figure 3. 


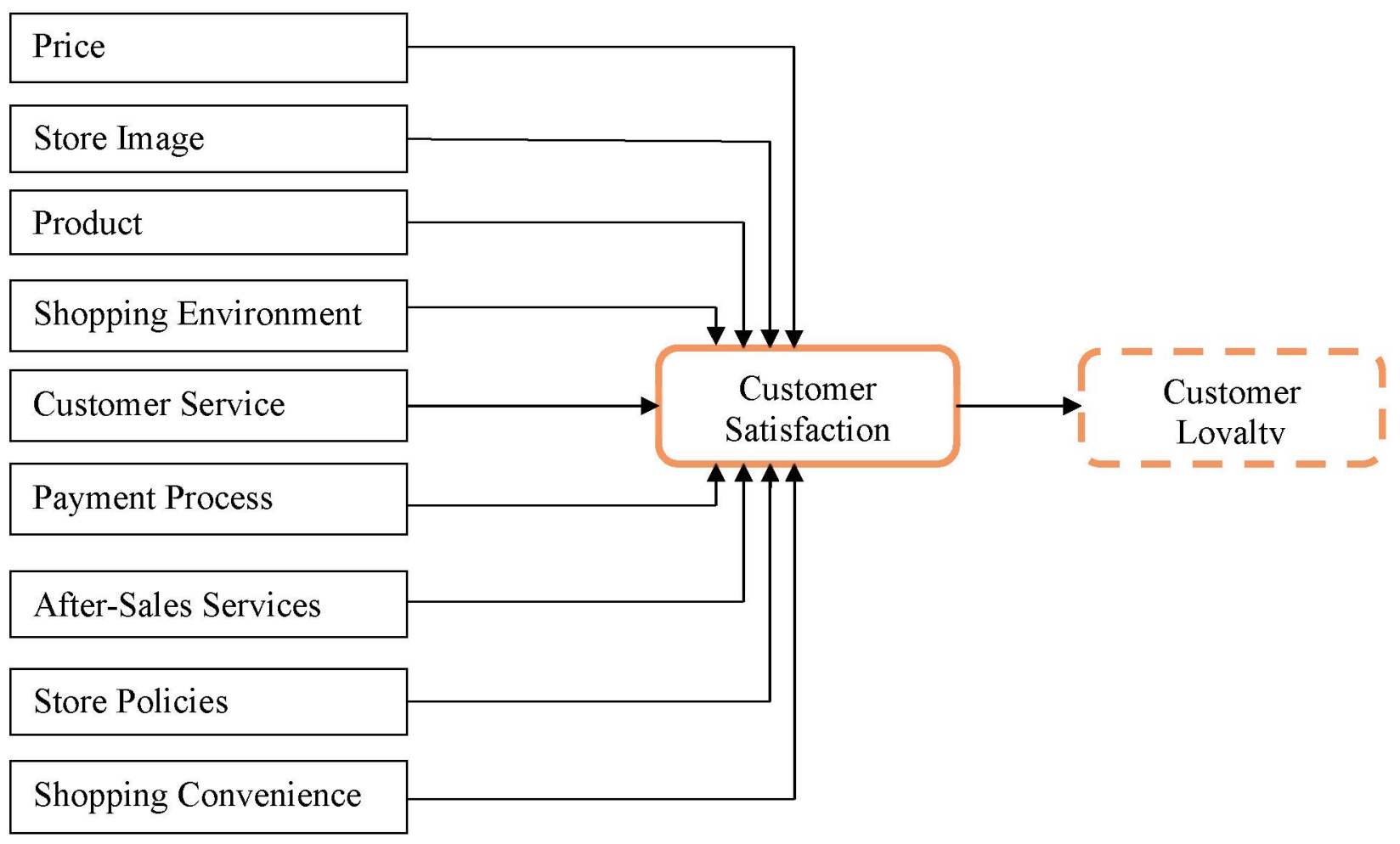

\section{Figure 3 An Exploratory model of factors influencing retail customer satisfaction}

Second, our results show that price is ranked as the most important attributes in hypermarkets and as the second most important attribute in electronic appliance speciality stores, influencing customer satisfaction. This result is consistent with the literature on some European markets where consumers use discount stores for their low prices in one shopping trip, such as in Germany (see Schmitz, 2009). However, this is an interesting difference to the US market where cleanliness is the most important attribute regardless of format (see Carpenter and Moore, 2006). It is also in contrast to the recent research conducted by Chang and Luan (2010), indicating that consumers in Beijing are more concerned with a retailer's reputation and services than price in hypermarkets. The difference may be due to the fact that our research was based on data from large cities across China rather than the capital alone. 
Third, for department stores, our results show that price is ranked as the fourth most important factor influencing customer satisfaction after store policies, after-sales services and store image. This is closer to the result presented by the US market, where price is not ranked in the top five most important attributes to customer satisfaction in hypermarkets (Carpenter and Moore, 2006). Given the fact that department store is one of the most traditional retail formats in China even before their update towards a more Western style of consumption (see Wang 2003), the decreased importance of price on customer satisfaction in department stores in China implies that when customers are more familiar with a retail format, they expect a higher level of service delivery from other aspects of retail offerings beyond price.

Despite the RBV emphasises the inimitability and isolating mechanisms (Hooley \& Greenlay, 2005) in competition with rivals, we argue that sustainable competitive advantages are also largely dependent on the stage of development of the retail format in a host market. In the case of an emerging market, such as China, the entry of large Western retailers in mid-1990s also introduced modern retail formats into the market such as hypermarkets, and new consumption patterns into department stores and electronic appliance speciality stores. Some of these retail formats and consumption patterns have already become traditional in developed markets such as in the US; however, there has not been a sufficient temporal phase of retail format development in which any distinctive benefit offered to emerging market consumers is likely to provide longterm sustainable competitive advantages. The relatively new consumption patterns that intend to create new customer experiences, such as the department stores that offer consumers full access to items (zi xuan shang chang), have yet been mature to assist retailers to achieve high sales performance in China. Therefore, we suggest that the key success factors indicated in our confirmed model can be shared by retailers for setting up their positioning strategies regardless 
of retail format in the Chinese market. Other examples include cost-reduction strategies have been recommended by Wang (2011) to retailers in the new competitive environment in China, e.g. a broad range of brands and products as well as marketing support from the suppliers are important factors for the successful up-market supermarkets and department stores in China (Kåre and Kjell, 2010).

\subsection{The RBV in the retail context in an emerging market}

Our chosen sample retailers present a successful retail cohort with a combination of both foreign and domestic retail firms. The RBV theory suggests that companies present and maintain their competitive advantages by having isolating mechanism. However, our results show that retailers in different retail formats are able to share similar/the same positioning strategies by providing similar/the same retail offerings to customers, and therefore achieve a similar level of success. The shared values expected from Chinese customers from various retail formats imply that strategic imitation particularly on price and store image among different retail firms is likely to form effective positioning strategies. The Western retailers have started to focus on experience innovation to co-create value and enable growth in productivity because they operate in mature economies with little increase in consumer expenditure (see Dawson, 2004); however, retailers (including Western retailers) in an emerging market such as China need to remain their focuses on traditional forms of innovation on the nine items suggested in our confirmed model, and create more values for customers during the development of their formats and store expansion.

We acknowledge that for the different retail formats customers seek homogeneous offerings, reflecting all the nine items in our confirmed model except for shopping convenience, which significantly influences customer satisfaction of department stores but not those of hypermarkets and electronic appliance speciality stores. According to our result, price is still the most 
important item that influences customer satisfaction of both hypermarkets and electronic appliance speciality stores. Chang and Luan (2010)'s finding is worth consideration here that store atmosphere is of most importance to Beijing customers in hypermarkets based on their data that were collected in the almost same period as those of this present research. However, our results show that the importance of store atmosphere is much less significant as one of the attributes in shopping environment. This implies that in large Chinese cities, consumer preferences have been evolving within a particular retail format. Overall, in order to be successful in the long run, retailers need to not only be competitive in price but also improve their corporate reputation as a whole. Furthermore, enhancing the awareness of customers' concept of value for money from a perceived price approach and improving customer's perceived value (Zeithaml, 1988) may both be alternative ways to succeed in an emerging market, because with further uptake of retail management practices from the Western markets, emerging market customers may start to look for better shopping experiences as well as low prices.

By providing alternative explanations to the RBV, we do not rule out the distinctive benefits different retailers offer as sustainable competitive advantages. In this regards, customers of hypermarkets and electronic appliance speciality stores expect lower price, better store image, better offerings on product, shopping environment, customer service, and faster payment process compared to customers of department stores. Any further improvements on these six items likely lead to a higher level of customer satisfaction for the former two retail formats.

Customers of department stores most concern about store policies and after-sales services as well as store image, which are the most influential determinants for their customer satisfaction. 
The traditional roles of the store policies are becoming less efficient to respond to the rapid growing demands for modern retail shopping experiences of Chinese customers. The store policies mainly refer to the complex exchange and refund systems inherited from the pre-reform era, which potentially push customers away to shop in other retail formats, such as hypermarkets. Regarding after-sales services, department stores also need to further improve their processes and efficiency of delivery, assembling and repair to establish a more innovative retail business model as suggested by Sorescu et al., (2011). These items are likely strongly related to their store image in positive ways. Moreover, customers of department stores expect better shopping convenience compared to those of hypermarkets and electrical appliance speciality stores. This is likely to be related to the traditional rules of department store shopping in China, where customers must get assistance to try on, try out or even see any product by oncounter services. In addition, they must make the payment first before they can put any items in their shopping baskets. This traditional shopping experience has been challenged by the modern retail formats transferred into China (Goldman, 2001) such as hypermarkets, where customers have free access to almost all items and where they are able to put them in their baskets/trolleys freely before checking out. Although customer loyalty of department stores remains relatively high, the lower customer satisfaction level towards store policies and after-sales services may further reduce the store image of this retail format and lead to a decreased level of customer loyalty in future.

From an organisational perspective, we identify that for the same retail formats, retailers have implemented different positioning strategies to attract customers. Some have offered one or more primary positioning items and/or secondary positioning items for their offerings, in line with the conclusions of Blankson and Kalafatis (2004). Others have no positioning item, which 
is challenging the views of Devlin et al. (1995) and Brooksbank (1994), who state that a firm's offering must be positioned in order to be successful in a long run. From this, it can be concluded that having clear positioning items may not be the only option for successful retail performance.

\section{Conclusions}

Through the application of the RBV, this paper aimed to investigate, from a customer perspective, which factors have an impact on customer satisfaction within the retail sector in an emerging market. We tested our drafted ten-item model containing factors of price, store image, product, shopping environment, customer service, payment process, after-sales services, store policies, store facilities, and shopping convenience based on the hypotheses set up. By analysing data obtained from a sample of 11,577 consumers from hypermarkets, electronic appliance speciality stores and department stores in major Chinese cities, our results completely rejected one hypothesis on store facilities (hypothesis 9) by all three retail formats and partially rejected another hypothesis on shopping convenience (hypothesis 10) by both hypermarkets and electronic appliance speciality stores. Thus, we confirm a nine-item model shown in Figure 3, which offers effective positioning choices for retailers in an emerging market.

According to our results, we contend that the anti-isolating mechanism and sharing similarities and values between retailers can be effective for success and maintaining sustainable competitive advantages at the development stage of retail expansion in an emerging market. In this regard, we emphasise the importance of homogeneity among retailers and our results show that successful positioning strategies are not much related to a specific retail format. We also found that a "successful" or a "towards-successful" retailer may not have a clear positioning item, despite the fact that all of the "successful" retailers have some of the nice items achieved 
their scores at an above those of the industrial average level. Our results challenge the idea of heterogeneous characteristics of competitive firms proposed by the RBV which implies that firms must have distinctive features compared to their rivals in order to become the winners. Among "towards-successful" retailers, except hypermarkets, which all have some of the nine items at an above the industrial average level, all the electrical appliance speciality stores and some of the department stores have all nine items with scores below those of the industrial average level. These phenomena call for more attention from some "towards-successful" electronic appliance speciality stores and "towards-successful" department stores to consideration of the nine items proposed in our confirmed new model. Furthermore, it is highly recommended that retailers consider that retailing learning in emerging market may be more important than imitation, as argued by Palmer (2006) that learning is much more persuasive than imitation although it requires the correct interpretation, evaluation and recognition of the knowledge and know-how implemented by rivals

The limitations of our study raise a future research agenda. In this paper, only three retail formats (i.e. hypermarkets, electronic appliance specialty stores and department stores) were considered for data collection. Many other emerging retail formats have also been introduced into China, including convenience stores, warehouse stores, membership clubs, discount stores, factory outlet, shopping malls, home improvement stores, and hybrid formats (see Wang, 2011). These new retail formats keep changing consumption patterns of Chinese consumers and are therefore worth investigating in future research. Moreover, coverage errors may have occurred for second- and third-tier Chinese cities, where consumption power has been growing. Therefore, future research is encouraged to obtain data from such cities to enable a comparison of the results. Furthermore, sample errors may have occurred in the random telephone 
interviewing process which might have left out those parts of the population or households that do not have a telephone (Blumberg et al., 2006). With further development of modern retail formats in China, more heterogeneous characteristics of retail positioning strategies, regardless of retail formats, may be seen at a later development stage for retail expansion. Therefore, a longitudinal study on a similar topic shall help to minimise sample errors as well as to provide more insights for the extension to the RBV theory. Theoretically both customer and organistional perspectives need to be closely linked when retail positioning strategies are in consideration. For example, a comparison study on what retailers offer from an organisational perspective and what consumers perceive from a customer perspective may provide an even clearer picture of effective retail positioning.

\section{References}

Amonini, C., McColl-Kennedy, J. R., Soutar, G. N., and Sweeney, J. C. (2010). How professional service firms compete in the market: an exploratory study. Journal of Marketing Management, 26, 1/2, 28-55.

Ander, N.W. and Stern, Z.N. (2004). Winning at Retail: Developing a Sustained Model for Retail Success, New Jersey, Hoboken: John Wiley \& Sons, Inc.

Arnett, D., Laverie, D. and Wilcox, J. (2010). A longitudinal examination of the effect of retailermanufacturer brand alliances: The role of perceived fit. Journal of Marketing Management, $26,1 / 2,5-27$.

Auken, S.V. and Lonial, S.C. (1991). Multidimentional Scaling and Retail Positioning: AN APPAISAL. International Journal of Retail \& Distribution Management, 19, 3, 11-18.

Au-Yeung, A.Y.S. (2003). International transfer of retail know-how through foreign direct investment from Europe to China. In J.A. Dawson, M. Mukoyama, S.C. Choi, \& R. Larke 
(Eds.), The internationalization of retailing in Asia, (p. 136). New York: Routledge Curzon Bhat, S. and Reddy, S.K. (1998). Symbolic and functional positioning of brands. Journal of Consumer Marketing, 15, 1, 32-43.

Babakus, E., Bienstock, C.C. and Van Scotter, J.R. (2004). Linking Perceived Quality and Customer Satisfaction to Store Traffic and Revenue Growth. Decision Sciences, 35, 713737.

Baker, J. and Cameron, M. (1996). The Effects of the Service Environment on Affect and Consumer Perception of Waiting Time: An Integrative Review and Research Propositions. Journal of the Academy of Marketing, 24, 4, 338-349.

Baker, J., Grewal, D. and Parasuraman, A. (1994). The Influence of Store Environment on Quality Inferences and Store Image. Journal of A cadenty of Marketing Science, 22, 4, 328339.

Baker, J, Levy, M. and Grewal, D. (1992). An Experiemental Approach to Marking Retail Store Environment Decisions. Journal of Retailing, 68, 4, 445-460.

Barney, J.B., (1986). Organizational Culture: Can It be a Source of Sustained Competitive Advantage? Academy of Management Review, 11, 3, 656-665.

Becker, G.S. (1965). A Theory of the Allocation of Time", Economic Journal, 75, 299, 493-517.

Beijing.gov (2006). Classification of Retail Format in China, available at: www.beijing.gov.cn/zfzx/tzgggs/bmtz/P020070412484468154814.doc in Chinese (accessed 04/06 2006).

Blankson, C. and Kalafatis, S.P. (2004). The development and validation of a scale measuring consumer/customer-derived generic typology of positioning strategies. Journal of Marketing Management, 20, 1, 5-43.

Bloemer, J. Ruyter, de K., and Peeters, P. (1998). Investigating drivers of bank loyalty: the 
complex relationship between image, service quality and satisfaction. International Journal of Bank Marketing, 16, 7, 276 - 286.

Blumberg, S., Lake, J. and Cynamon, M. (2006). Telephone coverage and health survey estimate: evaluating concerns about wireless substitutes. American Journal of Public Health, 96, 926-931.

Berman, B. and Evans, J.R. (2001). Retail management: A strategic approach. Upper Saddle River, NJ: Prentice Hall.

Brooksbank, R. (1994). The Anatomy of Marketing Positioning Strategy. Marketing Intelligence \& Planning. 12, 4, $10-14$.

Brown, S. (1987). A perceptual approach to retail agglomeration. Area, 19, 2, 131-140.

Byrne, B.M. (1998). Structural Equation Modeling with LISREL, PRELIS and SIMPLIS: Basic Concepts, Applications and Programming, Mahwah, New Jersey: Lawrence Erlbaum Associates.

Carpenter, J.M. and Moore, M. (2006). Consumer demographics, store attributes, and retail format choice in the US grocery market. International Journal of Retail and Distribution Management, 34, 6: $434-452$.

Chang, E. and Luan, B. (2010). Chinese consumers' perception of hypermarket store image. Asia Pacific Journal of Marketing and Logistics, 22, 4: 512 - 527.

China Chain Store Almanac (2005). Edited by China Chain Store and Franchise Association (Beijing: China Commercial Publisher).

Crawford, F. and Mathews, R. (2001). The Myth of Excellence: Why Great Companies Never Try to Be the Best at Everything, New York: Crown Business.

Crook, T.R., Ketchen Jr., D.J., Combs, J.G., and Todd, S.Y. 2008. Strategic resources and performance: A meta-analysis. Strategic Management Journal, 29, 1141-1154. 
Cronin, J.J. and Taylor, S.A. (1992). Measuring service quality: A re-examination and extension, Journal of Marketing, 56, 55-68.

Dabholkar, P.A., Thorpe, D.I. and Rentz, J. (1996). A Measure of Service Quality for Retail Stores: Scale Development and Validation. Journal of Academy of Marketing Science, 24, $1,3-14$.

Dawson, J. (2004). New Cultures, New Strategies, New Formats and New Relationships in European Retailing: Some implications for Asia. Journal of Global Marketing, 18, 1/2, 73 97.

Dawson, J. (2007). Scoping and conceptualising retailer internationalization. Journal of Economic Geography, 7, 373-397.

Dawson, J. (2013). Retailer activity in shaping food choice. Food Quality and Preference, 28, $339-347$.

Day, G.S. (2006). Achieving competitive advantage. In R.F Lusch and S.L.Vargo (Eds.), The Service Dominant Logic of marketing: Dialog, debate and direction, pp. 85-90. Armonk, NY: M.E. Sharpe.

Devlin, J., Ennew, C. and Mirza, M. (1995). Organisational positioning in retail financial services. Journal of Marketing Management, 11, 1-3, 119-132.

Dibb, S. and Simkin, L. (1993). The strength of branding and positioning in services. International Journal of Service Industry Management, 4, 1, 25-35.

Dibb, S., Simkin, L., Pride, W.M. and Ferrell, O.C. (1997). Marketing: Concepts and Strategies (3rd edn), Houghton Mifflin, Boston.

Dickson, P.R. and Sawyer, A.G. (1990). The Price Knowledge and Search of Supermarket Shoppers. Journal of Marketing, 54, July, 42-53.

Durvasula, S., Lysonski, S. and Mehta, S. C. (1999). Testing the SERVQUAL scale in the 
business-to-business sector: The case of ocean freight shipping service. Journal of Services Marketing, 13, 2, 132-148.

Euromonitor (2009). Retailing - China. Euromonitor International: Country Market Insight, May.

Fan, X., Thompson, B., and Wang, L. (1999). Effects of Sample Size, Estimation Methods, and Model Specification on Structural Equation Modeling Fit Indexes. Structural Equation Modeling, 6 1: 56-83.

Fornell, C. and Larcker, D.F. (1981). Evaluating structural equation models with unobservable variables and measurement error. Journal of Marketing Research, 18, February, 39-55.

Fowler, F.J. 2009. Survey Research Methods, Sage, London.

Goldman, A. (2001). The Transfer of Retail Formats into Developing Economics: The Example of China. Journal of Retailing, 77, 221-42.

Grant, R.M., (1991). The Resource-Based Theory of Competitive Advantage: Implications for Strategy Formulation. California Management Review, 33, 3, 114-135.

Grewal, D., Ailawadi, K.L, Gauri, D., Hall, K., Kopalle, P., and Robertson, J.R. (2011). Innovations in Retail Pricing and Promotions. Journal of Retailing, 87S, S43-S52.

Grewal, D., Baker, J., Levy, M. and Voss, G. (2003). The Effects Intentions in Service-Intensive Retail Stores. Journal of Retailing, 74, 3, 331-352.

Groves, R.M., Fowler, F.J., Couper, M. P., Lepkowski, J.M., Singer, E., and Tourangeau, R. (2004). Survey Methodology, Wiley, New York.

Hambrick, D. and Fredrickson, J. (2005). Are you sure you have a strategy? Academy of Management Executive, 194, 51-62.

Hanser, A. 2005. Made in PRC: China's consumer revolution. Current History, 104, 683, 272277. 
Heskett, J.L., Jones, T.O., Loveman, G.W., Sasser, W.E.Jr. and Schlesinger, L.A. (1994). Putting the service-profit chain to work, Harvard Business Review, 72, March-April, 163-174.

Hoffman, K.D. and Turley, L.W. (2002). Atmospherics, service encounters and consumer decision making: An integrative perspective. Journal of Marketing Theory and Practice, 10, $3,33-47$.

Hooley, G. and Greenley, G. (2005). The resource underpinnings of competitive positions. Journal of Strategic Marketing, 13, 2, 93-116.

Hooley, G.J. and Saunders, J.A. (1993). Competitive Positioning: The Key to Market Success, Prentice-Hall, New York, NY.

Hooley, G., Saunders, J. and Piercy, N. (2004). Marketing Strategy and Competitive Positioning, Prentice Hall, London.

Hooper, D., Coughlan, J. and Mullen, M. R. (2008). Structural Equation Modelling: Guidance for Determining Model Fit. Electronic Journal of Business Research Methods, 6, 1: 53-60.

Hu, L. and Bentler, P.M. (1999). Cutoff criteria for fit indexes in covariance structure analysis: Conventional criteria versus new alternatives. Structural Equation Modeling, 6, 1-55.

Hui, M.K., Dube, L. and Chebat, J. (1997). The Impact of Music on Consumers' Reactions to Waiting for Services. Journal of Retailing, 73, 1, 87-104.

Izquierdo, S.S., Izquierdo, L.R., Galán, J.M., Hernández, C. (2005). Market Failure caused by Quality Uncertainty", in: Mathieu P., Beaufils B. and Brandouy O. (Eds), Artificial Economics - Lecture Notes in Economics and Mathematical Systems, 564. Springer-Verlag, Berlin.

Johnson, M.D. and Gustafsson, A. (2000). Improving Customer Satisfaction, Loyalty and Profit: An Integrated Measurement and Management System. San Francisco, CA: Jossey-Bass.

Jöreskog, K. and Sörbom, D. (1993). LISREL 8: Structural equation modeling with the 
SIMPLIS command language. Erlbaum: Scientific Software International.

Kalafatis, S.P., Tsogas, M., and Blankson, C. (2000). Positioning strategies in business markets. Journal of Business and Industrial Marketing, 15, 6, 416-437.

Kåre, S. and Kjell, G (2010). Chinese food retailers' positioning strategies and the influence on their buying behaviour. Asia Pacific Journal of Marketing and Logistics, 22, 2: 196-209.

King, A. W. (2007). Disentangling interfirm and intrafirm causal ambiguity: A conceptual model of causal ambiguity and sustainable competitive advantage. Academy of Management Review, 32, 156-178.

Laurent, G. and Kapferer, J. (1985). Measuring Consumer Involvement Profiles. Journal of Marketing Research, 22, 41-53.

Lam, S.Y. (2001). The Effects of Store Environment on Shopping Behaviors: A Critical Review. Advances in Consumer Research, 28, 190-197.

Levy, M. and Weitz, B. (1995). Retailing Management. Chicago: Irwin.

Levy, M. and Weitz, B. (2007). Retailing Management. $6^{\text {th }}$ Edn. New York: McGraw-Hill Irwin. Lippman, S.A. and Rumelt, D.P., (1982). Uncertain Imitability: An Analysis of Interfirm Differences in Efficiency Under Competition. The Bell Journal of Economics, 13, 2, 418 438.

Lohmöller J.-B. (1989). Latent Variables Path Modeling with Partial Least Squares. Heildelberg: Physica-Verlag.

Lohr, S.L. (2008). Coverage and Sampling. In Leeuw, D. de., Hox, J. J. and Dillman, D. A. (Eds.), International Handbook of Survey Methodology, New York:Taylor \& Francis Group. Magretta J. (2002). Why Business Models Matter. Harvard Business Review, 80, 86-92. Martineau, P. (1958). The personality of the retail store. Harvard Business Review, 36, 1, 47-55. Matear, S., Gray, B., and Garrett, T. (2004). Market orientation, brand investment, new service 
development, market position and performance for service organization. International Journal of Service Industry Management, 15, 3/4, 284-301.

Mauri, A.J. and Michaels, M.P. (1998). Firm and industry effects within strategic management: an empirical examination. Strategic Management Journal. 19, 211-219

Mazursky, D. and Jacoby, J. (1985). Forming Impressions of Merchandise and Service Quality. In Jacob Jacoby and Jerry C Olson (Eds.), Perceived Quality How Consumers View Stores and Merchandise, MA: Lexington Books, Lexington, pp. 139-153.

Miles, J. and Shevlin, M. (1998). Effects of sample size, model specification and factor loadings on the GFI in confirmatory factor analysis. Personality and Individual Differences, 25, 8590

Moorman, C., Deshpandé, R. and Zaltman, G. (1993). Factors affecting trust in market research relationships. Journal of Marketing, 57, 81-101.

Nunnally, J.C. (1978), Psychometric Theory. New York: McGraw-Hill.

Oliver, R. (1981). Measurement and Evaluation of Satisfaction Processes in Retail Setting. Journal of Retailing, 57, Fall, 25-48.

Palmer, M. (2006). International retail joint venture learning. The Service Industries Journal, $26: 2,165-187$.

Penrose, E.T., (1959). The Theory of the Growth of the Firm, New York: Wiley

Peteraf, M.A. (1993). The Cornerstones of Competitive Advantage: A Resource-Based View. Strategic Management Journal, 14, 3, 179-191

Porter, M.E. (1980). Competitive Strategy, New York: The Free Press.

Porter, M.E. (1996). What is strategy? Harvard Business Review, 74, 6, 61-78.

Puccinelli, M.N., Goodstein, R.C., Grewal, D., Price, R., Raghubir, P., and Stewart, D. (2009). Customer Experience Management in Retailing: Understanding the Buying Process. Journal 
of Retailing, 85, 1, 15-30.

Ries, A. and Trout, J. (1986). Positioning: The Battle for Your Mind. New York: Warner Book.

Rothschild, M.L. (1979). Advertising Strategies for High and Low Involvement Situations. In Attitude Research Plays for High Stakes, J.C. Maloney and B. Silversman (Eds.). Chicago: American Marketing Association, 74-93.

Ryan, M.J., Buzas, T. and Ramaswamy, V. (1995). Making Customer Satisfaction Measurement a Power Tool. Marketing Research, 7, Summer, 11-16.

Rumelt, R. 1991. How much does industry matter? Strategic Management Journal, 12, 3: 167185.

Schmitz, G. (2009). The effects of acquisition and transaction shopping value perceptions on retail format usage intentions: an illustration from discount store. The International Review of Retail, Distribution and Consumer Research, 19, 2, 81-101.

Shoemaker, S. and Lewis, R.C. (1999). Customer loyalty: the Future of Hospitality Marketing. International Journal of Hospitality Management, 18, 4, 345-370.

Siebers, L.Q. (2011). Retail Internationalisation in China: Expansion of Foreign Retailers. Basingstoke: Palgrave MacMillan.

Siebers, L.Q. (2012). Foreign Retailers in China: the First Ten Years. Journal of Business Strategy, 33, $27-38$.

Siebers, L.Q. and Kamoche, K. (2012). Managing Human Resources in Retail MNEs in China. BAM conference, $11^{\text {th }}-13^{\text {th }}$ September, Cardiff, UK.

Sorescu, A., Frambach, R.T., Singh, J., Rangaswamy, A., and Bridges, C. (2011). Innovations in Retail Business Models. Journal of Retailing, 87s, 1, S3-S16.

Souitaris, V. and Balabanis, G. (2007). Tailoring Online Retail Strategies to Increase Customer Satisfaction and Loyalty Original Research Article. Long Range Planning, 40, 2, 244-261. 
Stanford, A.W, Singh, N. and Magnusson, P. (2012). Responsiveness to Global and Local Consumer Culture Positioning: A Personality and Collective Identity Perspective. Journal of International Marketing, 20, 1, 58-73.

Sweeney, J.C., Hausknecht, D. and Soutar, G.N. (2000). Cognitive Dissonance after Purchase: A Multidimensional Scale. Psychology \& Marketing, 17, 5, 369-385.

Thompson, K.E. and Chen, Y.L. (1998). Retail store image: a means-end approach. Journal of Marketing Practice: Applied Marketing Science, 4, 6, 161-173.

Titus, P.A., Everett, P.B. (1995). The consumer retail search process: a conceptual model and research agenda. Journal of Academy of Marketing Science, 23, 2, 106-20.

Treacy, M. and Wiersema, F. (1994). The Discipline of Market Leader. Reading: AddisonWesley, Mass.

Turley, L.W. and Milliman, R.E. (2000).Atmospheric Effects on Shopping Behavior: A Review of the Experimental Evidence. Journal of Business Research, 49, 2, 193-211.

Uncles, M.D. (2010). Retail change in China: retrospect and prospects. International Review of Retail, Distribution and Consumer Research, 20, 1: 69-84.

Van Kenhove, P. and Desumaux, P. (1997). The Relationship between Emotional States and Approach or Avoidance Responses in a Retail Environment. The International Review of Retail, Distribution and Consumer Research, 7, October, 351-368.

Walsh, G., Henning-Thurau, T., Sassenberg, K., and Bornemann, D. (2010). Does Relationship Quality Matter in E-Services? A Comparison of Online and Offline Retailing. Journal of Retailing and Consumer Services, 17, 2, 130-42.

Wang, E. (2011). Understanding the 'retail revolution' in urban China: a survey of retail formats in Beijing. The Service Industries Journal, 31, 2, 169-194.

Wang, S.G. (2003). Internationalisation of Retailing in China. In J. Dawson, M. Mukoyama, S.C. 
Choi and R. Larke (Eds). The Internationalisation of Retailing in Asia, pp.115-135. London: Routledge.

Wang, Y., Lo, P.H., Chi, R. and Yang Y. (2004). An integrated framework for customer value and customer-relationship-management performance: a customer-based perspective from China. Managing Service Quality, 14, 2/3: 169 - 182.

Ward, J.C., Bitner, M.J. and Barnes, J. (1992). Measuring the Prototypicality and Meaning of Retail Environments. Journal of Retailing, 68, 2, 194-220.

Wernerfelt, B. (1984). The Resource-Based View of the Firm. Strategic Management Journal, 5, $2,171-180$

Westbrook, R.A. (1981). Sources of Consumer Satisfaction with Retail Outlets. Journal of Retailing, 57, Fall, 68-85.

Zeithaml, V.A. (1988). Consumer perceptions of price, quality and value: A means-end model and synthesis of evidence. Journal of Marketing, 52, 3, 2-22.

Zeithaml, V.A., Barry, L.L. and parasuraman, A. (1996). The Behavioural Consequences of Service Quality. Journal of Marketing, 60, 2, 31-46. 
Table 1 A synthesis of literature on positioning strategies and customer satisfaction

\begin{tabular}{|l|l|}
\hline $\begin{array}{l}\text { Retail } \\
\text { positioning } \\
\text { strategies }\end{array}$ & Elements influencing customer satisfaction (literature and sources) \\
\hline Perceived price & $\begin{array}{l}\text { Price (Crawford and Mathews, 2001); low prices (Ander and Stern, } \\
\text { 2004); perceived price (Rothschild, 1979; Laurent and Kapferer, 1985; } \\
\text { Zeithaml, 1988); effectiveness of promotion (Grewal et al., 2011) }\end{array}$ \\
\hline Store image & $\begin{array}{l}\text { Emotional added value (Martineau, 1958); customer intimacy (Treacy } \\
\text { and Wiersema, 1994); nice feeling and reputation (Thompson and Chen, } \\
\text { 1998); patronage intentions (Grewal et al., 2003) }\end{array}$ \\
\hline $\begin{array}{l}\text { Product } \\
\text { environment } \\
\text { (including store } \\
\text { facilities) }\end{array}$ & $\begin{array}{l}\text { Product leadership (Treacy and Wiersema, 1994); product (Crawford } \\
\text { and Mathews, 2001); variety of products, fashion (Ander and Stern, } \\
\text { 2004); innovation and uniqueness (Hooley et al., 2004) }\end{array}$ \\
\hline $\begin{array}{l}\text { Service quality } \\
\text { (including } \\
\text { customer service } \\
\text { and store } \\
\text { policies) }\end{array}$ & $\begin{array}{l}\text { Cameron); store layout (Titus and Everett, 1995); lighting (Baker and } \\
\text { 1994); engagement and fun (Puccinelli et al., 2009) }\end{array}$ \\
$\begin{array}{l}\text { Service quality (Cronin and Taylor, 1992; Dabholkar et al., 1996); } \\
\text { experience and services (Crawford and Mathews, 2001); technical } \\
\text { quality and service (Hooley et al., 2004); in store experience - } \\
\text { interaction with employees and merchandise (Westbrook, 1981); refund } \\
\text { or exchange merchandise (Mazursky and Jacoby, 1985); store policies } \\
\text { (Dabholkar et al., 1996) }\end{array}$ \\
\hline $\begin{array}{l}\text { Shopping } \\
\text { convenience }\end{array}$ & $\begin{array}{l}\text { Access (Crawford and Mathews, 2001); convenience and efficiency } \\
\text { (Ander and Stern, 2004) }\end{array}$ \\
\hline
\end{tabular}


Table 2 Mean values of each dimension for three retail formats

\begin{tabular}{|l|c|c|c|}
\hline Variable & Hypermarkets & $\begin{array}{c}\text { Electronic } \\
\text { appliances }\end{array}$ & Department stores \\
\cline { 2 - 4 } & Mean & Mean & Mean \\
\hline Perceived price & 6.93 & 7.10 & 6.36 \\
\hline Store image & 7.56 & 7.70 & 7.08 \\
\hline Product & 7.52 & 7.60 & 6.99 \\
\hline Shopping environment & 7.55 & 7.42 & 7.04 \\
\hline Customer service & 7.04 & 7.16 & 6.81 \\
\hline Payment process & 7.79 & 8.13 & 7.21 \\
\hline After-sales service & 7.04 & 7.36 & 6.58 \\
\hline Store policies & 7.01 & 6.83 & 6.47 \\
\hline Store facilities & 6.40 & 5.42 & 6.26 \\
\hline Shopping convenience & 7.64 & 7.05 & 6.59 \\
\hline Customer satisfaction & 7.37 & 7.44 & 6.75 \\
\hline Customer loyalty & 6.38 & 6.37 & 6.59 \\
\hline
\end{tabular}

Table 3 Verification of scale analysis (10-item model)

\begin{tabular}{|l|l|l|l|}
\hline & Hypermarkets & $\begin{array}{l}\text { Electrical appliance } \\
\text { speciality stores }\end{array}$ & $\begin{array}{l}\text { Department } \\
\text { stores }\end{array}$ \\
\hline RMSEA & 0.058 & 0.057 & 0.059 \\
\hline SRMR & 0.031 & 0.034 & 0.035 \\
\hline GFI & 0.91 & 0.90 & 0.88 \\
\hline AGFI & 0.89 & 0.88 & 0.85 \\
\hline NNFI & 0.92 & 0.93 & 0.91 \\
\hline CFI & 0.93 & 0.94 & 0.93 \\
\hline
\end{tabular}


Table 4 PLS analysis results

\begin{tabular}{|c|c|c|c|c|c|c|c|c|c|}
\hline \multirow[b]{2}{*}{ Factors } & \multicolumn{9}{|c|}{ Impact on customer satisfaction } \\
\hline & $\begin{array}{l}\text { Hyper- } \\
\text { markets }\end{array}$ & $\begin{array}{l}\alpha \\
\text { value }\end{array}$ & $\begin{array}{l}\mathrm{p} \\
\text { value }\end{array}$ & $\begin{array}{l}\text { Electrical } \\
\text { appliance } \\
\text { stores }\end{array}$ & $\begin{array}{l}\alpha \\
\text { value }\end{array}$ & $\begin{array}{l}p \\
\text { value }\end{array}$ & $\begin{array}{l}\text { Department } \\
\text { stores }\end{array}$ & $\begin{array}{l}\alpha \\
\text { value }\end{array}$ & $\begin{array}{l}\mathrm{p} \\
\text { value }\end{array}$ \\
\hline Price & $0.26^{* * *}$ & \multirow[t]{4}{*}{0.83} & \multirow[t]{4}{*}{0.000} & $0.24^{* * *}$ & \multirow[t]{4}{*}{0.82} & \multirow[t]{4}{*}{0.000} & $0.11 * * *$ & \multirow[t]{4}{*}{0.86} & \multirow[t]{4}{*}{0.000} \\
\hline Reasonable price & 0.37 & & & 0.40 & & & 0.27 & & \\
\hline Competitive price & 0.40 & & & 0.41 & & & 0.23 & & \\
\hline Attractive promotion & 0.37 & & & 0.38 & & & 0.25 & & \\
\hline Store image & $0.18 * * * *$ & \multirow[t]{5}{*}{0.84} & \multirow[t]{5}{*}{0.000} & $0.27^{* * *}$ & \multirow[t]{5}{*}{0.85} & \multirow[t]{5}{*}{0.000} & $0.16^{* * *}$ & \multirow[t]{5}{*}{0.86} & \multirow[t]{5}{*}{0.000} \\
\hline Famousness & 0.27 & & & 0.25 & & & 0.23 & & \\
\hline Store reputation & 0.31 & & & 0.32 & & & 0.30 & & \\
\hline Trust & 0.32 & & & 0.33 & & & 0.335 & & \\
\hline Social responsibility & 0.32 & & & 0.31 & & & 0.33 & & \\
\hline Product & $0.17^{* * *}$ & \multirow[t]{5}{*}{0.84} & \multirow[t]{5}{*}{0.000} & $0.09^{* * *}$ & \multirow[t]{5}{*}{0.83} & \multirow[t]{5}{*}{0.000} & $0.07 * * *$ & \multirow[t]{5}{*}{0.86} & \multirow[t]{5}{*}{0.000} \\
\hline Top of the range & 0.31 & & & 0.29 & & & 0.246 & & \\
\hline Easy to be found & 0.30 & & & 0.30 & & & 0.268 & & \\
\hline Neat display & 0.31 & & & 0.31 & & & 0.268 & & \\
\hline Quality & 0.31 & & & 0.34 & & & 0.247 & & \\
\hline Shopping environment & $0.08^{* * *}$ & \multirow[t]{5}{*}{0.86} & 0.000 & $0.09^{* * *}$ & 0.86 & 0.000 & $0.06^{* * *}$ & 0.87 & 0.000 \\
\hline Spaciousness & 0.28 & & & 0.30 & & & 0.30 & & \\
\hline Cleanness & 0.30 & & & 0.29 & & & 0.30 & & \\
\hline Atmosphere & 0.31 & & & 0.31 & & & 0.29 & & \\
\hline Layout & 0.31 & & & 0.32 & & & 0.31 & & \\
\hline Customer service & $0.11 * * *$ & 0.93 & 0.000 & $0.15^{* * *}$ & 0.93 & 0.000 & $0.09 * * *$ & 0.91 & 0.000 \\
\hline Willingness to help & 0.19 & & & 0.21 & & & 0.20 & & \\
\hline Ability to help & 0.182 & & & 0.20 & & & 0.20 & & \\
\hline Appearance \& behaviour & 0.192 & & & 0.19 & & & 0.20 & & \\
\hline Attitude & 0.20 & & & 0.18 & & & 0.20 & & \\
\hline Reliability & 0.20 & & & 0.21 & & & 0.21 & & \\
\hline Prompt help & 0.182 & & & 0.20 & & & 0.20 & & \\
\hline Payment process & $0.05^{* * *}$ & 0.77 & 0.000 & $0.07 * * *$ & 0.77 & 0.000 & $0.03^{* * *}$ & 0.78 & 0.000 \\
\hline Checkout accuracy & 0.38 & & & 0.38 & & & 0.38 & & \\
\hline Payment methods & 0.41 & & & 0.41 & & & 0.41 & & \\
\hline Checkout speed & 0.42 & & & 0.43 & & & 0.41 & & \\
\hline After-sales service & $0.04^{* * *}$ & 0.80 & 0.000 & $0.07 * * *$ & 0.75 & 0.001 & $0.16^{* * *}$ & 0.78 & 0.000 \\
\hline Prompt delivery \& assembling & 0.56 & & & 0.58 & & & 0.55 & & \\
\hline Prompt repair & 0.53 & & & 0.54 & & & 0.55 & & \\
\hline Store policies & $0.03^{* * *}$ & - & 0.000 & $0.02^{* * * *}$ & - & 0.000 & $0.30^{* * *}$ & 0.80 & 0.000 \\
\hline Refund policies & & & & & & & 0.40 & & \\
\hline Store facilities & 0.01 & 0.71 & 0.052 & 0.03 & 0.70 & 0.052 & -0.00 & 0.80 & 0.100 \\
\hline Trolleys \& baskets & 0.47 & & & - & & & 0.41 (lift) & & \\
\hline Washrooms & 0.39 & & & 0.54 & & & 0.39 & & \\
\hline Rest facilities & 0.41 & & & 0.60 & & & 0.38 & & \\
\hline Shopping convenience & 0.01 & 0.61 & 0.528 & 0.00 & 0.61 & 0.528 & $0.03^{* * *}$ & 0.75 & 0.000 \\
\hline Opening hours & 0.39 & & & 0.39 & & & 0.31 & & \\
\hline Convenient location & 0.30 & & & 0.33 & & & 0.26 & & \\
\hline Easy parking & 0.34 & & & 0.38 & & & 0.27 & & \\
\hline $\begin{array}{l}\text { Easy storage of personnel } \\
\text { belongings }\end{array}$ & 0.43 & & & 0.39 & & & 0.28 & & \\
\hline
\end{tabular}

(The evaluation score is referred to the average industrial level; *** refers to variables with $\mathrm{p}<0.001$; '-' this factor has only one item) 


\section{Table 5 Retail offerings of hypermarket, electronic appliance speciality stores and}

department stores

\begin{tabular}{|c|c|c|c|c|c|}
\hline \multicolumn{6}{|c|}{ Part I Retail offerings of hypermarkets } \\
\hline & Retailers & Primary positioning items & $\begin{array}{l}\text { Retail } \\
\text { offerings }\end{array}$ & $\begin{array}{l}\text { Secondary } \\
\text { positioning items }\end{array}$ & $\begin{array}{l}\text { Non-positioning } \\
\text { items }\end{array}$ \\
\hline \multirow{7}{*}{$\begin{array}{l}\text { Successful } \\
\text { retailers }\end{array}$} & Auchans & Low prices & Price & $\begin{array}{l}\text { Parking \& bag } \\
\text { keeping }\end{array}$ & 5 items $>$ average \\
\hline & Da Runfa & Flexible refund policies & Service & Promotion & 6 items $>$ average \\
\hline & Wal-Mart & Comfortable environment & Environment & Quality & 7 items $>$ average \\
\hline & Metro & Variety of products & Products & Not clear & 8 items $>$ average \\
\hline & JUSCO & Efficient customer service & Service & Store facilities & 6 items $>$ average \\
\hline & Huatang & Efficient customer service & Service & Store facilities & 5 items $>$ average \\
\hline & Hymall, Carrefour & Not clear & Not clear & Not clear & 7 items $>$ average \\
\hline $\begin{array}{l}\text { Towards- } \\
\text { successful } \\
\text { retailers }\end{array}$ & $\begin{array}{l}\text { Shenzhen Baijia, } \\
\text { Beijing Hualian, } \\
\text { Shanghai } \\
\text { Gongnongshang, } \\
\text { Lotus, Suguo, } \\
\text { Beijing Wumei, Hao } \\
\text { Youduo, Makro, Xin } \\
\text { Yijia, Huarun Wanjia, } \\
\text { Shanghai Hualian } \\
\text { Shngahai Lianhua }\end{array}$ & Not clear & Not clear & Not clear & $\begin{array}{l}7 \text { items }>\text { average } \\
\text { (Makro); } 2 \text { items }> \\
\text { average (Hao Youduo } \\
\& \text { Lotus); } 1 \text { item }> \\
\text { average (Suguo); } \\
\text { others have } 9 \text { items = } \\
\text { average level }\end{array}$ \\
\hline \multicolumn{6}{|c|}{ Part II Retail offerings of electrical appliance speciality stores } \\
\hline & Retailers & Primary positioning items & $\begin{array}{l}\text { Retail } \\
\text { offerings }\end{array}$ & $\begin{array}{l}\text { Secondary } \\
\text { positioning items }\end{array}$ & $\begin{array}{l}\text { Non-positioning } \\
\text { items }\end{array}$ \\
\hline \multirow{3}{*}{$\begin{array}{l}\text { Successful } \\
\text { retailers }\end{array}$} & Sanlian & Not clear & Not clear & Not clear & 9 items $>$ average \\
\hline & Wuxing & After-sales service & Service & Payment process & 7 items $>$ average \\
\hline & Guomei & Low price & Price & Variety of products & 7 items $>$ average \\
\hline $\begin{array}{l}\text { Towards- } \\
\text { successful } \\
\text { retailers }\end{array}$ & $\begin{array}{l}\text { Suning, } \\
\text { Dazhong, } \\
\text { Yongle } \\
\end{array}$ & Not clear & Not clear & Not clear & $\begin{array}{l}\text { All items } \leq \text { average } \\
\text { level }\end{array}$ \\
\hline \multicolumn{6}{|c|}{ Part III Retail offerings of department stores } \\
\hline & Retailers & Primary positioning item & $\begin{array}{l}\text { Retail } \\
\text { offerings }\end{array}$ & $\begin{array}{l}\text { Secondary } \\
\text { positioning items }\end{array}$ & $\begin{array}{l}\text { Non-positioning } \\
\text { items }\end{array}$ \\
\hline \multirow{4}{*}{$\begin{array}{l}\text { Successful } \\
\text { retailers }\end{array}$} & Saite Purchase Centre & Flexible refund policies & Service & Quality & 6 items $>$ average \\
\hline & $\begin{array}{l}\text { Beijing Cuiwei } \\
\text { Mansion }\end{array}$ & Store environment & Environment & Customer service & 7 items $>$ average \\
\hline & $\begin{array}{l}\text { Shanghai No.1 } \\
\text { Babaiban }\end{array}$ & Store policies & Polices & Customer service & 7 items $>$ average \\
\hline & Beijing WangFujing & Not clear & Not clear & Not clear & 4 items $>$ average \\
\hline \multirow{3}{*}{$\begin{array}{l}\text { Towards- } \\
\text { successful } \\
\text { retailers }\end{array}$} & Beijing Baisheng & Payment process & Service & Store policies & 2 items $>$ average \\
\hline & $\begin{array}{l}\text { Shanghai Pacific- Xu } \\
\text { Jiahui branch }\end{array}$ & Price perception & Price & Customer service & 3 items $>$ average \\
\hline & $\begin{array}{l}\text { Yansha Friendship } \\
\text { Shopping Mall, } \\
\text { Shanghai East } \\
\text { Mansion, Shanhai } \\
\text { New World }\end{array}$ & Not clear & Not clear & Not clear & $\begin{array}{l}\text { some have } 6 \text { items }> \\
\text { average; some have } 9 \\
\text { items }<\text { average }\end{array}$ \\
\hline
\end{tabular}


Appendix 1 Sample characteristics

\begin{tabular}{|c|c|c|c|c|c|c|}
\hline & \multicolumn{2}{|c|}{ Hypermarkets } & \multicolumn{2}{|c|}{$\begin{array}{l}\text { Electronic appliance } \\
\text { speciality stores }\end{array}$} & \multicolumn{2}{|c|}{ Department stores } \\
\hline \multicolumn{7}{|l|}{ Age } \\
\hline $18-34$ & \multicolumn{2}{|l|}{$54.3 \%$} & \multicolumn{2}{|l|}{$52.9 \%$} & \multicolumn{2}{|l|}{$79.8 \%$} \\
\hline $35-59$ & \multicolumn{2}{|l|}{$34.8 \%$} & \multicolumn{2}{|l|}{$38.2 \%$} & \multicolumn{2}{|l|}{$19.7 \%$} \\
\hline $60+$ & \multicolumn{2}{|l|}{$10.9 \%$} & \multicolumn{2}{|l|}{$8.9 \%$} & \multicolumn{2}{|l|}{$0.5 \%$} \\
\hline \multicolumn{7}{|l|}{ Sex } \\
\hline Male & \multicolumn{2}{|l|}{$44 \%$} & \multicolumn{2}{|l|}{$51 \%$} & \multicolumn{2}{|l|}{$55 \%$} \\
\hline Female & \multicolumn{2}{|l|}{$56 \%$} & \multicolumn{2}{|l|}{$49 \%$} & \multicolumn{2}{|l|}{$45 \%$} \\
\hline \multicolumn{7}{|l|}{ Level of education } \\
\hline Elementary & \multicolumn{2}{|l|}{$1.6 \%$} & \multicolumn{2}{|l|}{$1.8 \%$} & \multicolumn{2}{|l|}{$0.7 \%$} \\
\hline Middle School & $11.2 \%$ & & $11.1 \%$ & & $3.3 \%$ & \\
\hline High School & $34.7 \%$ & & $31.9 \%$ & & $13.0 \%$ & \\
\hline College/university & $52.5 \%$ & & $51.3 \%$ & & $83.0 \%$ & \\
\hline Family income (RMB) & & & & & & \\
\hline$<5,000$ & $4.3 \%$ & & $3.3 \%$ & & $6.1 \%$ & \\
\hline $5,100-20,000$ & $24.7 \%$ & & $21.0 \%$ & & $18.3 \%$ & \\
\hline $21,000-45,000$ & $30.5 \%$ & & $30.4 \%$ & & $34.5 \%$ & \\
\hline $45,100-80,000$ & $24.7 \%$ & & $27.1 \%$ & & $22.9 \%$ & \\
\hline $80,100-100,000$ & $6.9 \%$ & & $6.5 \%$ & & $7.5 \%$ & \\
\hline $101,000+$ & $9.0 \%$ & & $11.7 \%$ & & $10.6 \%$ & \\
\hline Transportation & & & & & & \\
\hline Free shopping service & $5 \%$ & & $1 \%$ & & $8 \%$ & \\
\hline Foot & $37 \%$ & & $24 \%$ & & $15 \%$ & \\
\hline Bicycle & $12 \%$ & & $10 \%$ & & $7 \%$ & \\
\hline $\mathrm{Car}$ & $15 \%$ & & $20 \%$ & & $10 \%$ & \\
\hline Public transport & $28 \%$ & & $39 \%$ & & $49 \%$ & \\
\hline Other & $3 \%$ & & $6 \%$ & & $11 \%$ (taxi) & \\
\hline $\begin{array}{l}\text { Purchase duration } \\
\text { (minutes) }\end{array}$ & & & & & & \\
\hline $1-40$ & $39.1 \%$ & & $41.1 \%$ & & $21.7 \%$ & \\
\hline $41-60$ & $38.9 \%$ & & $35.1 \%$ & & $41.8 \%$ & \\
\hline $61-90$ & $7.1 \%$ & & $6.5 \%$ & & $12.5 \%$ & \\
\hline $91-120$ & $11.4 \%$ & & $11.6 \%$ & & $16.8 \%$ & \\
\hline $120+$ & $3.5 \%$ & & $5.7 \%$ & & $7.2 \%$ & \\
\hline & RMB & & RMB & & RMB & \\
\hline Average expenditure & $0-50$ & $23.8 \%$ & $0-500$ & $22.3 \%$ & $0-100$ & $25.9 \%$ \\
\hline & $51-150$ & $49.1 \%$ & $501-2,000$ & $41.5 \%$ & $101-300$ & $31.4 \%$ \\
\hline & $151-250$ & $14.9 \%$ & $2,000-4000$ & $19.0 \%$ & $301-500$ & $15.8 \%$ \\
\hline & $250-300$ & $4.1 \%$ & $4,000-5,000$ & $5.2 \%$ & $501-1,000$ & $17.4 \%$ \\
\hline & $300+$ & $8.1 \%$ & $5,000+$ & $12.0 \%$ & $>1,000$ & $9.5 \%$ \\
\hline Shopping frequency & Times/m & & Last visit ( $\mathrm{n}$ & nths) & Last visit & onths) \\
\hline & $1-2$ & $55.7 \%$ & $1-3$ & $53.3 \%$ & 1 & $86.7 \%$ \\
\hline & $3-4$ & $23.0 \%$ & $4-6$ & $30.3 \%$ & $2-3$ & $4.8 \%$ \\
\hline & $5+$ & $21.3 \%$ & $7-12$ & $16.4 \%$ & $3+$ & $8.5 \%$ \\
\hline
\end{tabular}

